\title{
Mantle-derived fluids in the Nankai Trough Kumano forearc basin
}

\author{
Thomas Wiersberg $^{1^{*}} \mathbb{D}$, Sebastian B. Hammerschmidt ${ }^{2}$, Shigeshi Fuchida ${ }^{3}$, Achim Kopf $^{2}$ and Jörg Erzinger ${ }^{1}$
}

\begin{abstract}
Noble gas abundance and isotope data from 12 drilling mud gas samples obtained during IODP Expeditions 338 and 348 provide new insights on fluid origin and fluid migration in the inner accretionary prism below the Kumano forearc basin offshore SE Japan. The samples originate from three adjoining boreholes (C0002F, C0002N and C0002P) spanning depths between 950 and 3050 meters below sea floor (mbsf) and are composed of air and variable contributions of mantle-derived and crustal fluids.

Air-corrected ${ }^{3} \mathrm{He} /{ }^{4} \mathrm{He}$ ratios of samples from Exp. 338 fall between $0.44 \pm 0.24$ Ra and $3.26 \pm 0.28$ Ra. Samples $\# 1400$ and \#1800 (sample number denotes depth in mbsf) are more influenced by radiogenic helium (1.33 \pm 0.34 Ra resp. $0.44 \pm 0.24 \mathrm{Ra}$ ), whereas the air-free helium isotopic composition of sample \#950 is clearly higher (3.26 $0.28 \mathrm{Ra}$ ). Enhanced radon activity around $950 \mathrm{mbsf}, 1100 \mathrm{mbsf}, 1400 \mathrm{mbsf}$, and $1800 \mathrm{mbsf}$ suggests active flow of fluids at these depths.

The helium isotopic composition of two other samples (\#1700 and \#1850) collected during Exp. 338 and of all samples obtained during the 1-year-later Exp. 348 are less variable $\left(1.74-2.46\right.$ Ra with a mean ${ }^{3} \mathrm{He} /{ }^{4} \mathrm{He}$ ratio of $\sim 2.4 \mathrm{Ra}$ ) and no radon anomalies were observed during sampling. For these samples, we assume migration by diffusive flow of helium-bearing fluids through sediments of the accretionary prism. In contrast, elevated radon activities and the more variable helium isotopic composition of fluids from 950, 1400, and 1800 mbsf from Exp. 338 are better explained by channelized and active fluid flow through temporarily permeable strata, maybe as a short-term episodic flow event caused by reactivation of buried trust faults. The helium isotopic composition of \#950 is in good agreement with estimated helium isotope values of the subducting Philippine Sea Plate (PSP) at present ( 3.4 Ra), whereas fluids from 1400 and 1800 mbsf demonstrate the input of radiogenic helium from a crustal, probably terrestrial source.
\end{abstract}

Keywords: Helium isotopes, Radon, Fluid flow, Nankai Trough, Integrated Ocean Drilling Program

\section{Introduction}

The Kumano forearc basin is located SE of the Kii Peninsula (Fig. 1) and is one of the most studied forearc basins in the Nankai Trough region and worldwide. It has been explored by several riser and non-riser drilling operations over the course of the Integrated Ocean Drilling Program (IODP) Nankai Trough Seismogenic Zone Experiment (NanTroSEIZE). Samples and data discussed in the following were obtained during IODP NanTroSEIZE Expeditions 338 (Strasser et al. 2014a, 2014b, 2014c) and 348

\footnotetext{
*Correspondence: wiers@gfz-potsdam.de

${ }^{1}$ Helmholtz Centre Potsdam, GFZ German Research Centre for Geosciences,

Telegrafenberg, D-14473 Potsdam, Germany

Full list of author information is available at the end of the article
}

(Expedition 348 Scientists and Scientific Participants 2014; Tobin et al. 2015).

Recent 3-D seismic reflection surveys report the presence of several normal faults cutting through the forearc basin (Moore et al. 2009, 2015; Kinoshita et al. 2018), which could serve as possible migration pathways for aqueous fluids and dissolved and free gases. Common fluid migration features at convergent margins, particularly in the Kumano forearc basin, are mud volcanoes, through which fluids and gases are expelled to the hydro- and atmosphere. Mud volcanoes can serve as "tectonic windows" to processes operating at greater depths (e.g. Kopf 2002), where the presence of gases significantly enhances mud mobilization. Gas samples taken from mud volcanoes in the Kumano forearc basin showed a clear thermogenic 


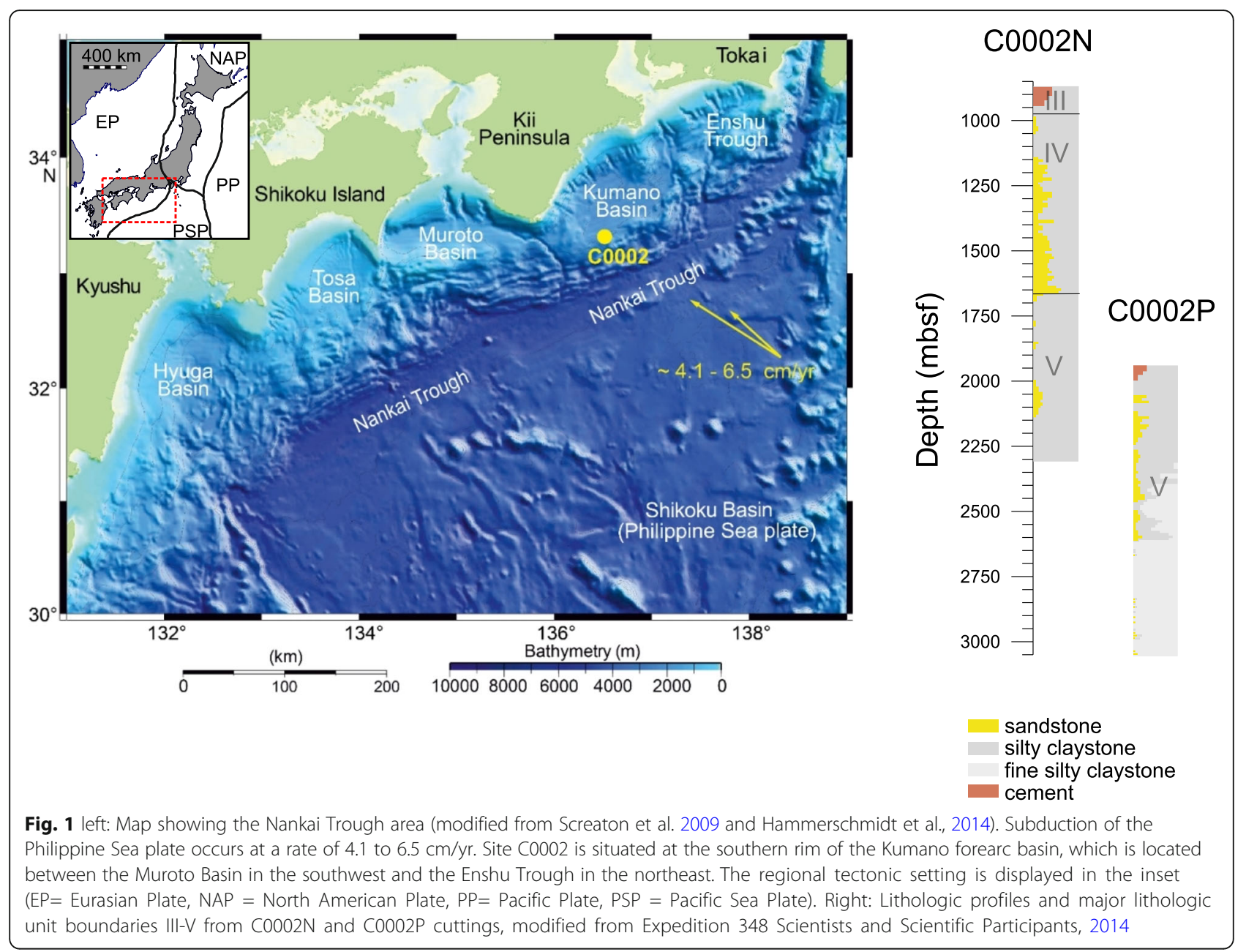

signal $\left(\delta^{13} \mathrm{C} \geq-40 \%\right.$ PDB). The overall TOC values of hemipelagic mudstones in the Kumano forearc basin are low, but cutting samples from C0009 (Unit III), located $20 \mathrm{~km}$ northwest of Site C0002, are partly enriched in organic material (Doan et al. 2011; Wiersberg et al. 2015). However, formation temperatures and the maturity of the organic material (wood, lignite) are too low to generate significant amounts of thermogenic methane (Wiersberg et al. 2015); it is therefore believed that thermogenic methane from mud volcanos derives from old accreted sediments underlying the basin sediments (Pape et al. 2014). Further landward in the Kumano Basin at IODP Site C0009, the molecular composition of hydrocarbons and the carbon isotope composition of methane $\left({ }^{13} \mathrm{C} \sim-66 \% \mathrm{PDB}\right)$ in drilling mud gas indicate the presence of microbial methane with only little evidence for mixing with thermogenic hydrocarbons (Wiersberg et al. 2015), making upward migration of deep-sourced gases at this site unlikely.

Drilling mud gas monitoring and sampling at IODP Site C0002 at the southern rim of the Kumano forearc basin revealed the overall dominance of microbial methane to depths down to 1700 mbsf (Hammerschmidt et al. 2014) with increasing contribution of thermogenic gas at greater depth. Estimated formation temperatures at $1700 \mathrm{mbsf}$, based on long-term temperature monitoring at C0002 (Sugihara et al. 2014), fall between 65 and $70{ }^{\circ} \mathrm{C}$, depending on the assumed thermal conductivity. Although this temperature range marks also the beginning of thermogenic gas generation (Whiticar 1994), the low TOC content at depths below 1700 mbsf at Site C0002 (Tobin et al., 2015) makes significant in situ generation of hydrocarbons by thermal degradation of organic matter little likely. Indeed, we favour migration of thermogenic gas from deeper sources and mixing with shallow bacterial hydrocarbon gas. Evidence for migration of deeper fluids in the Nankai Trough subduction zone is also provided by lithium, iodine and boron isotopes studies (Nishio et al. 2015, Tomaru and Fehn 2014, Hüpers et al. 2016). Unusual light ${ }^{7} \mathrm{Li} /{ }^{6} \mathrm{Li}$ ratios in fluids recovered from a Kumano mud volcano (Nishio et al. 2015) are in line with estimated temperatures of up to $310{ }^{\circ} \mathrm{C}$, indicating a deep lithium-bearing fluid source. Iodine ages of pore water samples from C0002 at depths as deep as $984 \mathrm{mbsf}$ are significantly older than ages of the host sediments, 
iodine must thus have been transported from deeper formations older than $25 \mathrm{Ma}$ (Tomaru and Fehn 2014). Boron concentration and isotope data from silt and sand layers (Hüpers et al. 2016) of the underthrust section of the downgoing plate at Nankai favour fluid flow in seaward direction from depths equivalent to the temperature range of $60^{\circ} \mathrm{C}$ to $150{ }^{\circ} \mathrm{C}$.

Noble gas isotopes like ${ }^{222} \mathrm{Rn},{ }^{3} \mathrm{He}$ and ${ }^{4} \mathrm{He}$ are useful tools to distinguish between active fluid flow through permeable strata and trapping of pore fluids in pore space. ${ }^{222} \mathrm{Rn}$ and ${ }^{4} \mathrm{He}$ are products of the radioactive decay of the parent elements uranium $(\mathrm{U})$ respectively uranium plus thorium $(\mathrm{U}+\mathrm{Th})$, while ${ }^{3} \mathrm{He}$ is mainly primordial and associated with mantle-derived fluids. Helium and to a greater extend radon are soluble in water and can be easily transported by active fluid flow. However, while both helium isotopes ${ }^{3} \mathrm{He}$ and ${ }^{4} \mathrm{He}$ are stable, all radon isotopes are subject to further radioactive decay. The most stable isotope of radon, ${ }^{222} \mathrm{Rn}$, has a half-life of 3.8 days, and contrary to $\mathrm{He},{ }^{222} \mathrm{Rn}$ is characterized by a low diffusivity. Consequently, high concentrations of $\mathrm{He}$ and low concentrations of ${ }^{222} \mathrm{Rn}$ suggest high porosity and low permeability, whereas high concentrations of ${ }^{222} \mathrm{Rn}$ and He point to rapid fluid flow. High permeability can be further identified using the ${ }^{3} \mathrm{He} /{ }^{4} \mathrm{He}$ isotope ratio (e.g. Aquilina et al. 1998; Kennedy et al. 1997; Wiersberg and Erzinger 2007, 2011; Burnard et al. 2012), which can even indicate active crustal deformation and enhancement in local permeability (Kennedy and van Soest 2007). Aquilina et al. (1998) found ${ }^{3} \mathrm{He} /{ }^{4} \mathrm{He}$ ratios of $\sim 0.3 \mathrm{Ra}$ in drilling mud gas samples from a borehole that penetrates Triassic sandstones of the northeastern edge of the SE Basin of France. The authors suggest mantle fluid flow from a deeper source into the investigated Triassic reservoirs. The source of mantle fluids is probably related to the rise of the mantle in the Alpine zones and Rhodanian corridor. Kennedy (1997) and Wiersberg and Erzinger (2007, 2011) investigated surface respectively borehole fluids from the SAF. In the absence of recent magmatism around the sampling spots at the SAF, the elevated helium isotope ratios reported in these studies indicate enhanced crustal permeability, promoting fault-controlled advective mantle fluid flow through the brittle-ductile barrier to the surface. The wide spatial distribution of mantle fluids in the SA Fault Zone could be explained by injection of mantle fluids from fluid-bearing faults into the country rock, followed by diffusion. Significant variations in helium isotope compositions on short spatial scale are reported from the San Andreas Fault at seismogenic depths (Wiersberg and Erzinger 2011) and were interpreted as episodic and channelized fluid. Kennedy and van Soest (2007) investigated helium isotopes in surface fluids from the northern Basin and Range Province in the western USA. Helium isotope trends correlate with rates of crustal deformation, caused by the motion of the North American relative to the Pacific Plate, where highest ${ }^{3} \mathrm{He} /{ }^{4} \mathrm{He}$ ratios coincide with greatest extension and shear strain.

Helium isotopes are typically reported as ${ }^{3} \mathrm{He} /{ }^{4} \mathrm{He}$ ratio and denoted in atmospheric ratios $\left(\mathrm{Ra},\left({ }^{3} \mathrm{He} /{ }^{4} \mathrm{He}\right)_{\text {air }} \equiv\right.$ $\left.1.388 \times 10^{-6} \equiv 1 \mathrm{Ra}\right)$. A helium isotope composition of $0.02 \mathrm{Ra}$ is typical for fluids from crustal sources (Mamyrin and Tolstikhin 1984), whereas ratios of $>1 \mathrm{Ra}$ demonstrate the presence of helium from primordial (i.e. mantle) He sources (Clark et al. 1969).

${ }^{3} \mathrm{He} /{ }^{4} \mathrm{He}$ isotope ratios have been reported from plate margins worldwide, e.g. from the Indonesian archipelango (Hilton and Craig 1989), circum-pacific volcanic arcs (Poreda and Craig 1989), the Indian Ocean Ridge (Moreira et al. 2003), from mud volcanoes at the Caucasian continental collision zone (Kopf et al. 2003) and the Congo-Angola margin (Chaduteau et al. 2009) and the eastern and western Pacific Ocean (Chavrit et al. 2016). Hilton et al. (2002) provide a summary of helium isotope variations in arc-related geothermal and volcanic fluids worldwide. In southwest Japan, $\mathrm{He}$ isotope ratios from the back-arc region show values similar to the mean ratio of $5.4 \pm 1.9 \mathrm{Ra}$ for arc-related volcanism (Hilton et al. 2002). At the Kii Peninsula, ${ }^{3} \mathrm{He} /{ }^{4} \mathrm{He}$ ratios are between 1 and 5.4 $\mathrm{Ra}$ and show a spatial distribution approximately parallel to the Nankai Trough itself, explained by the upward flow of mantle volatiles originating from the mantle wedge overlying the subducting Philippine Sea Plate (PSP), or from the hydrated mantle of the subducting slab (Wakita et al. 1987, Matsumoto et al. 2003, Doğan et al. 2006, Umeda et al. 2006a, 2006b, 2007a, 2007b, 2012, Sano and Nakajima 2008, Sano et al., 2009). In the forearc region, He isotope ratios are generally lower. Umeda et al. (2012) calculated a helium isotope composition of $\leq 3.4 \mathrm{Ra}$ for the subducting PSP at the present time, considering the subduction of oceanic lithosphere of mid-Miocene age which has undergone altering of the original helium isotope composition (8 Ra) by helium diffusive lost and post-intrusive ingrowth of radiogenic ${ }^{4} \mathrm{He}$ from $\mathrm{U}$ and $\mathrm{Th}$ decay in the tholeiite basalts (Sano and Nakajima 2008).

Here we report results from helium isotope ratios $\left({ }^{3} \mathrm{He} /{ }^{4} \mathrm{He}\right)$ from 12 drilling mud gas samples taken during IODP Expeditions 338 and 348 (Strasser et al. 2014a, 2014b, 2014c; Expedition 348 Scientists and Scientific Participants 2014; Tobin et al. 2015). During both expeditions, riser drilling was conducted in the Kumano forearc basin, southeast offshore the Kii Peninsula (Site C0002; Fig. 1). The drilling operation commenced in Kumano Basin sediments at around 
$850 \mathrm{mbsf}$ and stopped at around $3050 \mathrm{mbsf}$ in the accretionary prism. The entire interval was subjected to drilling mud gas monitoring and sampling during riser drilling. We explore possible contributions of mantle-derived and crustal helium in the depth interval 950-3050 mbsf and discuss our findings in the context of fluid migration through the accretionary prism. Our data also provide a seaward extension of previously compiled $\mathrm{He}$ isotope ratio dataset for southeast Japan (Umeda et al. 2012).

\section{Geological background}

The Nankai Trough, located southeast of the eastern coast of southern Japan, was formed mainly during the Oligocene-Miocene period by a complex subduction-accretion process that probably included migration of a triple junction (Kimura et al. 2014; Underwood 2018). The northwest directed subduction of the PSP beneath the Eurasian Plate initiated around $\sim 15 \mathrm{Ma}$, temporarily ceased at $\sim 12 \mathrm{Ma}$ and restarted at $\sim 6 \mathrm{Ma}$ (e.g. Taira 2001; Kimura et al. 2014), forming the Kumano forearc basin (Hayman et al. 2012) and resulting in today's subduction rates of ca. 4.1-6.5 cm/year (Seno et al. 1993; Miyazaki and Heki 2001). A major splay fault (Megasplay fault) within an out-of-sequence-thrust (OOST) fault system separates the inner from the outer accretionary prism overlying the seismogenic and aseismic part of the thrust fault boundary, respectively (Wang and $\mathrm{Hu}$ 2006). The Megasplay fault system is suggested to be hydraulically connected to the thrust fault boundary (e.g. Tobin and Saffer 2009). Splay fault activity in the accretionary prism significantly promoted sedimentation in the Kumano forearc basin at around 1.67-1.56 Ma (Strasser et al. 2009).

Site C0002 is situated at the southern rim of the Kumano forearc basin, in the so-called "forearc basin zone" (Moore et al. 2009, 2013; Ashi et al. 2009; Kopf et al. 2011). Based on coring and logging data, the Expedition 315 Scientists (2009, Hole C0002B), Strasser et al. (2014c, Holes C0002F, H, J, K, L) and the Expedition 348 Scientists (2014, Holes C0002N, P) recognized five different lithological units in the southern part of the Kumano forearc basin at Site C0002. Unit I (down to $474 \mathrm{mbsf}$ ), Unit II (475-875.5 mbsf in Hole C0002M), Unit III (875.5-975.5 mbsf in Hole C0002N), Unit IV (975.5-1665.5 mbsf in Hole C0002N) and Unit V (1665.5-2325.5 mbsf in Hole C0002N and 1965.5-3058.5 mbsf in Hole C0002P).

Unit I is comprised of mud of clayey silt to silty clay, in which foraminifers are abundant. Unit II is also dominated by mud (clayey silt to silty clay), with silty to sandy interbeds. Unit II is generally coarser than Unit I and is interpreted to consist of distal basin deposits (Expedition 315 Scientists 2009). Unit
III comprises basal forearc basin sediments, which are characterized by silty claystone with abundant occurrence of calcareous nannofossils and dewatering structures as well as scattered bioturbation and glauconite-rich zones (Expedition 315 Scientists 2009). Unit IV is interpreted to be the upper accretionary prism, based on a remarkable increase in interbedding of mud-, silt- and sandstone in an otherwise mudstone-dominated interval. Unit IV is further characterized by a decrease in calcareous nannofossils and intense tectonic deformation. Between $1665 \mathrm{mbsf}$ and $1701 \mathrm{mbsf}$, the lithology becomes predominantly silty claystone, which defines the top boundary Unit V.

In hole C0002B (Exp 315), faults were clustering in two intervals from 920 to $950 \mathrm{mbsf}$ and from 1000 to 1050 mbsf. These two fault clusters display the greatest range in dip as well as the highest dip magnitude (i.e. $90^{\circ}$ at $920 \mathrm{mbsf}$ ) of all of the faults at this site. The upper cluster of faults is just below the top of Unit IV, although a few faults are also present above the boundary. Expedition 315 Scientists interpreted the upper cluster as a system of out-of-sequence (splay) faults and a significant unconformity at $\sim 922$ mbsf as a manifestation of uplift along these faults that occurred at $\sim 5 \mathrm{Ma}$ (Expedition 315 Scientists 2009). In Hole C0002P, the Unit V top and bottom boundaries are located at 1965.5 and 3058.5 mbsf, respectively; therefore, the top boundary is $300 \mathrm{~m}$ deeper than in Hole C0002B. Based on calcareous nannofossil assemblages, Unit $\mathrm{V}$ is most likely of Miocene age. The cored interval within Unit V (2163-2219 mbsf) revealed a prominent fault zone at 2205-2206 mbsf.

Strasser et al. (2014c) and Expedition 348 Scientists and Scientific Participants (2014) concluded that Unit $\mathrm{V}$ is either trench or Shikoku Basin sediment. However, most of the sediments deposited in the Shikoku Basin between 10.5 and $5.6 \mathrm{Ma}$ contain substantially higher proportions of smectite (Underwood 2018) than mudstones with corresponding ages at site C0002 (depth interval 1400-2400 mbsf, see Table 1). Such discrepancies in bulk mineralogy between accreted mudstones at $\mathrm{C0002}$ and coeval deposits in the Shikoku Basin call for different origins of sediments. Underwood (2018) suggests a mixed origin for C0002 strata that includes input of sediments from the subducting plate Pacific Plate.

\section{Methodology and data evaluation}

A suite of 12 drilling mud gas samples was collected during IODP Expedition 338 between October 2012 and January 2013 and Expedition 348 between September 2013 and January 2014 for noble gas isotope analysis. Samples from Expedition 338 were taken during riser drilling of Hole C0002F (875.5$2005.6 \mathrm{mbsf})$, while samples from Expedition 348 
Table 1 Formation ages and the QMS gas composition data from 12 drilling mud gas samples from IODP Expeditions 338 and 348 covering the depth range $950-3050$ mbsf. Analytical errors are $\pm 20 \%$ for helium and $\pm 5 \%$ for all other gases. Formation ages from nannofossils, C0002F: Strasser et al. 2014c; C0002N/P: Tobin et al., 2014

\begin{tabular}{|c|c|c|c|c|c|c|c|}
\hline Sample \# [mbsf] & Expedition/ Hole & Formation age $[\mathrm{Ma}]^{\mathrm{a}}$ & He (ppmv) & $\operatorname{Ar}(\operatorname{vol} . \%)$ & $\mathrm{N}_{2}$ (vol.\%) & $\mathrm{O}_{2}$ (vol.\%) & $\mathrm{CH}_{4}$ (vol.\%) \\
\hline 950 & $338 / \mathrm{CO} 002 \mathrm{~F}$ & $3.79-5.59$ & 6.8 & 0.93 & 74.8 & 19.2 & 4.98 \\
\hline 1400 & $338 / \mathrm{CO} 002 \mathrm{~F}$ & $>5.59$ & 6.9 & 0.98 & 77.9 & 20.5 & 0.50 \\
\hline 1700 & $338 / C 0002 F$ & $>5.59$ & 6.7 & 1.00 & 78.2 & 20.3 & 0.43 \\
\hline 1800 & $338 / \mathrm{CO} 002 \mathrm{~F}$ & $>5.59$ & 6.7 & 0.96 & 78.6 & 20.3 & 0.19 \\
\hline 1850 & $338 / C 0002 F$ & $>5.59$ & 6.6 & 1.01 & 78.2 & 20.4 & 0.22 \\
\hline 2050 & $348 / \mathrm{CO002N}$ & $\leq 7.362-7.424$ & 8.1 & 0.93 & 78.8 & 20.1 & 0.07 \\
\hline 2200 & $348 / \mathrm{CO002N}$ & $\leq 9.35$ & 8.0 & 0.92 & 80.0 & 19.8 & 0.12 \\
\hline $2349.5 \mathrm{~A}$ & $348 / C 0002 P$ & $\leq 10.541$ & 7.9 & 0.93 & 78.8 & 20.1 & 0.20 \\
\hline 2349.5 B & $348 / C 0002 P$ & $\leq 10.541$ & n.a. & n.a. & n.a. & n.a. & n.a. \\
\hline 2850 & $348 / C 0002 P$ & $\leq 10.72$ & 8.3 & 0.91 & 79.3 & 19.5 & 0.25 \\
\hline 2968.5 & $348 / C 0002 P$ & $\leq 10.72$ & 8.5 & 0.90 & 78.2 & 18.9 & 1.91 \\
\hline 3050 & $348 / C 0002 P$ & $\leq 10.72$ & 8.0 & 0.92 & 79.3 & 19.5 & 0.23 \\
\hline
\end{tabular}

n.a not analysed

${ }^{\text {a}}$ Formation ages from nannofossils (C0002F: Strasser et al. 2014c; C0002N/P: Tobin et al., 2014)

were obtained from Hole C0002N (875.5-2325.5 mbsf) and C0002P (1965.5-3058.5 mbsf). In total, the samples cover a depth range from 950 to 3050 mbsf. The lateral distance between Hole $\mathrm{C} 0002 \mathrm{~F}$ and $\mathrm{C} 0002 \mathrm{~N}$ is $16 \mathrm{~m}$, and $39 \mathrm{~m}$ between Hole C0002N and Hole C0002P. Holes C0002F and C0002P are $55 \mathrm{~m}$ apart.

${ }^{222} \mathrm{Rn}$ decay was monitored in drilling mud gas during drilling of Holes C0002F, C0002N and C0002P with a 650-mL ion-counting chamber in sampling intervals of $10 \mathrm{~min}$, a sensitivity of $100 \mathrm{~Bq} / \mathrm{m}^{3}$ and a concentration range between 2 and $2 \times 10^{6} \mathrm{~Bq} / \mathrm{m}^{3}$ (Strasser et al. 2014b; Expedition 348 Scientists and Scientific Participants 2014).

Gas samples for noble gas analysis were taken from the gas line after gas extraction from the circulating drilling mud. All sampling times and corresponding sample depths were corrected for lag time, i.e. the time the formation gas needs to travel from the bottom of the borehole to the gas-monitoring instruments. The drilling mud gas-monitoring method is reported by Erzinger et al. (2006). The drilling mud gas-monitoring system onboard $\mathrm{D} / \mathrm{V}$ Chikyu is described in detail in Hammerschmidt (2014). It should be noted that drilling mud is open to air at the mud tanks; hence, a significant portion of the gas extracted from the circulating drilling mud derives from the atmosphere. The gas samples were collected in glass cylinders equipped with two stopcocks following a method described by Hilton et al. (2002).

To avoid significant helium loss from the sample cylinders during sample storage by diffusion, noble gas isotope analysis was conducted within 4 months after sample arrival in the noble gas laboratory. Prior to noble gas isotope analysis, the samples were analysed with a quadrupole mass spectrometer for $\mathrm{He}$, $\mathrm{N}_{2}, \mathrm{O}_{2}, \mathrm{CH}_{4}, \mathrm{CO}_{2}$ and Ar with detection limits of $1 \mathrm{ppm}$ by volume (ppmv) for $\mathrm{He}, \mathrm{CH}_{4}$ and $\mathrm{Ar}$, as well as $10 \mathrm{ppmv}$ for $\mathrm{O}_{2}, \mathrm{~N}_{2}$ and $\mathrm{CO}_{2}$ to prove sample integrity and identify possible diffusion loss and additional air contamination (Table 1).

Noble gas isotope analysis was conducted in the noble gas laboratory of the German Research Centre for Geosciences (GFZ). The determination of noble gas concentrations and isotopic compositions follow protocols described in detail by Niedermann et al. (1997). Here, we present a short summary of the analytical procedure that comprises gas inlet, purification, mass spectrometric analysis and data processing.

The procedure for noble gas isotope analyses includes purification, a mass spectrometric analysis using a VG 5400 mass spectrometer and data processing (see Niedermann et al. (1997) for a comprehensive explanation and statistical evaluation of the procedure). An aliquot with a predefined volume is introduced in the system under a constant pressure. The gas split is transferred to the purification line, where vaporized water is extracted by a dry-ice cooled cold trap. Removal of nitrogen, oxygen and carbon dioxide is accomplished by passing the sample to two titanium sponge getters, which are heated to ca. $1024 \mathrm{~K}$ and $674 \mathrm{~K}$, respectively. The setup also comprises two $\mathrm{Zr}$-Al getters, which extract hydrogen, hydrocarbons and remaining carbon dioxide. Prior to the helium and neon analyses, argon, krypton and xenon are separated from the gas phase by two nitrogen-cooled charcoal fingers. 
The remaining gas is transferred to two cryogenic cold heads that have temperatures of $50 \mathrm{~K}$ and $11 \mathrm{~K}$, respectively. The former allows adsorption of remaining argon, krypton and xenon. Helium and neon are collected with the second cold head. Temperature-controlled release is used to determine noble gas concentrations. For $\mathrm{He}$, the second cryogenic cold head is heated to $35 \mathrm{~K}$, which is followed by a step-wise increase in temperature of the first cold head to measure argon (80 K), krypton (100 K) and xenon (190 K). Afterwards, $\mathrm{Ne}$ is released by heating the second cold head to $120 \mathrm{~K}$. For He and Ne measurements, background concentrations of argon and hydrocarbons were suppressed by a stainless steel frit and an activated charcoal finger that was cooled with liquid nitrogen.

The measurements in this study were corrected for initial ("blank") gas concentrations and influences of atmospheric gas following Niedermann et al. (1997, and references therein. Concentrations of the blanks (in $\mathrm{cm}^{3}$ STP) were typically: ${ }^{4} \mathrm{He} \sim 5 \times 10^{-12},{ }^{20} \mathrm{Ne} \sim 0.5 \times 10^{-12}$, ${ }^{40} \mathrm{Ar} \sim 5 \times 10^{-10},{ }^{84} \mathrm{Kr} \sim 0.05 \times 10^{-12}$ and ${ }^{132} \mathrm{Xe} \sim 0.02 \times$ $10^{-12}$ (Niedermann et al. 1997; Wiersberg et al. 2011). These concentrations were all well below the concentrations in the samples; therefore, a blank correction was not necessary. The influence of isobaric interferences is minimized by correlating the mass spectrometer background values with the efficiency for double-charged ion production (Niedermann et al. 1997).

Except for helium, all noble gas isotope ratios and ${ }^{20} \mathrm{Ne}$-normalized abundances of all samples are, within $2 \sigma$ analytical uncertainties, indistinguishable from air. Helium in drilling mud gas derives from air plus variable contribution of crustal helium $\left({ }^{3} \mathrm{He} /{ }^{4} \mathrm{He}<0.1 \mathrm{Ra}\right.$, typically $0.02 \mathrm{Ra}$, Mamyrin and Tolstikhin 1984) and mantle-derived helium $\left({ }^{3} \mathrm{He} /{ }^{4} \mathrm{He}>1 \mathrm{Ra}\right.$, typically $6 \mathrm{Ra}$ for the lithospheric mantle (Dunai and Baur 1995) and $8 \pm 1$ Ra for the MORB mantle endmember (Graham 2002)). Due to the high abundance of air in drilling mud gas, measured ${ }^{3} \mathrm{He} /{ }^{4} \mathrm{He}$ ratios have to be corrected for air. Assuming that ${ }^{20} \mathrm{Ne}$ in the samples is of purely atmospheric origin, which was confirmed for our study by neon isotopic analysis, the correction is done according to methods described by Craig et al. (1978) and Ballentine and Burnard (2002). The correction for atmospheric helium is very sensitive to the ${ }^{4} \mathrm{He} /{ }^{20} \mathrm{Ne}$ ratio assumed for the atmospheric component, which can be either the ratio of air (0.319) or of air-saturated water ASW $(<0.319$, depending on temperature and salinity of the water). To test if atmospheric helium derives from air or ASW, we have calculated the ${ }^{20} \mathrm{Ne}$ and ${ }^{40} \mathrm{Ar}$ equilibrium concentrations in seawater for different temperatures according to Kipfer et al. (2002). In a diagram of ${ }^{20} \mathrm{Ne}$ versus ${ }^{40} \mathrm{Ar}$ (Fig. 2), all data points plot on the line that displays a variable contribution of a non-fractionated atmospheric component, clearly distinct from calculated air-saturated ${ }^{20} \mathrm{Ne} /{ }^{40} \mathrm{Ar}$ ratios in seawater at $4{ }^{\circ} \mathrm{C}$ and $20^{\circ}$
C. Therefore, we assume an unfractionated atmospheric component with ${ }^{4} \mathrm{He} /{ }^{20} \mathrm{Ne}=0.319$ being present in our samples.

\section{Results}

Shipboard results, including ${ }^{222} \mathrm{Rn}$, are comprehensively outlined in Strasser et al. (2014c) and Expedition 348 Scientists and Scientific Participants (2014). Here, the main findings will be briefly reviewed. At C0002F, ${ }^{222} \mathrm{Rn}$ was peaking around 950 mbsf, 1100 mbsf, $1400 \mathrm{mbsf}$ and 1800 mbsf, which can be interpreted as active fluid inflow (see, e.g. Aquilina et al. 1998) into the borehole. Gas samples from 950, 1400 and 1800 mbsf also show atypical ${ }^{3} \mathrm{He} /{ }^{4} \mathrm{He}$ isotope ratios (from $1100 \mathrm{mbsf}$, we do not have a gas sample). Surprisingly, during re-drilling this interval in Hole $\mathrm{C} 0002 \mathrm{~N}$, the concentrations of ${ }^{222} \mathrm{Rn}$ remained low (below $100 \mathrm{~Bq} / \mathrm{m}^{3}$ ) but show maximum activities $\left(\leq 200 \mathrm{~Bq} / \mathrm{m}^{3}\right)$ between 2050 and 2100 mbsf and below $2210 \mathrm{mbsf}$. For the depth interval 1965.5-2325 mbsf, which was penetrated by both holes, C0002N and C0002P, radon measurements show much higher activity for C0002P, albeit no significant radon peaks between 2050 and $2100 \mathrm{mbsf}$ and below 2210 mbsf, as it was the case for C0002N. C0002P displays a general trend of increasing radon activity down to $\sim 2500$ mbsf with local maxima at $\sim 2090$ and 2160 mbsf. Below $\sim 2500$ mbsf, radon activities in C0002P, albeit showing some variations, are relatively constant with $\sim 250 \mathrm{~Bq} / \mathrm{m}^{3}$.

Table 1 shows formation ages and the QMS gas composition data from 12 drilling mud gas samples from IODP Expeditions 338 and 348 covering the depth range 950-3050 mbsf. Analytical errors are $\pm 20 \%$ for helium and $\pm 5 \%$ for all other gases. Noble gas nuclide abundances $\left({ }^{4} \mathrm{He},{ }^{20} \mathrm{Ne},{ }^{40} \mathrm{Ar},{ }^{84} \mathrm{Kr}\right.$ and $\left.{ }^{132} \mathrm{Xe}\right)$, isotope ratios $\left({ }^{3} \mathrm{He} /{ }^{4} \mathrm{He}, \quad{ }^{20} \mathrm{Ne} /{ }^{22} \mathrm{Ne}, \quad{ }^{21} \mathrm{Ne} /{ }^{22} \mathrm{Ne}, \quad{ }^{40} \mathrm{Ar} /{ }^{36} \mathrm{Ar}\right.$, and $\left.{ }^{38} \mathrm{Ar} /{ }^{36} \mathrm{Ar}\right)$, nuclide ratios $\left({ }^{4} \mathrm{He} /{ }^{20} \mathrm{Ne}\right.$ and $\left.{ }^{3} \mathrm{He} /{ }^{20} \mathrm{Ne}\right)$, air-corrected ${ }^{3} \mathrm{He} /{ }^{4} \mathrm{He}$ ratios and the relative proportions of atmospheric, crustal and mantle helium from the same 12 samples are shown in Table 2.

Abundances of the noble gas nuclides ${ }^{4} \mathrm{He},{ }^{20} \mathrm{Ne},{ }^{40} \mathrm{Ar}$, ${ }^{84} \mathrm{Kr}$ and ${ }^{132} \mathrm{Xe}$ are denoted in millibar (mbar). For ${ }^{20} \mathrm{Ne}$, ${ }^{40} \mathrm{Ar},{ }^{84} \mathrm{Kr}$ and ${ }^{132} \mathrm{Xe}$, some samples show abundances higher than air, while others are lower, with a general trend of increasing nuclide concentrations with depth. Gas samples with noble gas nuclide abundances higher than air show oxygen concentration in the gas phase lower than the atmosphere, probably due to chemical consumption of oxygen during the drilling process. In turn, gas samples with noble gas abundances lower than air contain additional formation gases (methane), which reduces the noble gas abundances. However, for all samples, the ${ }^{20} \mathrm{Ne}$ normalized noble gas nuclide abundance $\left(\mathrm{X} /{ }^{20} \mathrm{Ne}\right)$ are atmospheric for ${ }^{40} \mathrm{Ar},{ }^{84} \mathrm{Kr}$ and ${ }^{132} \mathrm{Xe}$. In 


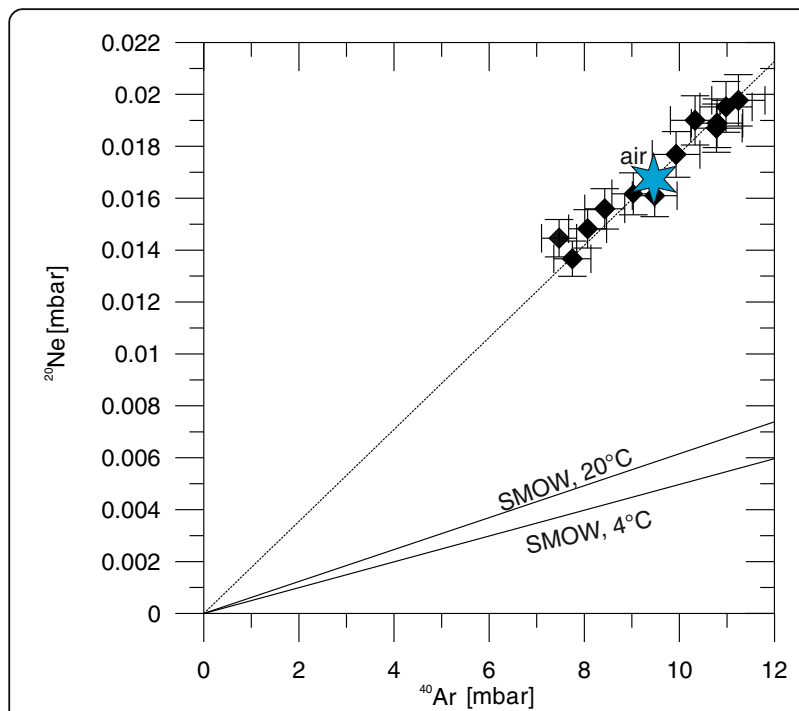

Fig. $2{ }^{20} \mathrm{Ne}$ vs. ${ }^{40} \mathrm{Ar}$ diagram showing lines for variable contributions of air (dashed line) and for air-saturated standard mean ocean water (SMOW) at $4{ }^{\circ} \mathrm{C}$ and $20^{\circ} \mathrm{C}$. All data points fall on the mixing line with air

contrast, ${ }^{3} \mathrm{He} /{ }^{20} \mathrm{Ne}$ and ${ }^{4} \mathrm{He} /{ }^{20} \mathrm{Ne}$ ratios are higher than atmospheric for all samples, indicating the presence of helium-bearing formation fluids.

Diagrams ${ }^{3} \mathrm{He} /{ }^{20} \mathrm{Ne}$ vs. ${ }^{4} \mathrm{He} /{ }^{20} \mathrm{Ne}$ (Fig. 3a) and ${ }^{3} \mathrm{He} /{ }^{4} \mathrm{He}$ vs. ${ }^{4} \mathrm{He} /{ }^{20} \mathrm{Ne}$ (Fig. 3b) are suitable to identifying mixing of fluids with different helium isotope compositions. In both plots, the data from nine of the 12 samples (\#1700, \#1850 from Exp 338 and all samples from Exp 348) fall on mixing lines which indicate binary mixing between air and one component containing mantle-derived helium. The helium isotope composition of this mantle component can be estimated by averaging, weighted by errors, of the air-corrected ${ }^{3} \mathrm{He} /{ }^{4} \mathrm{He}$ ratios of these nine samples, which yields a ${ }^{3} \mathrm{He} /{ }^{4} \mathrm{He}$ ratio of $2.40 \pm 0.10 \mathrm{Ra}$. The samples \#950 mbsf, \#1400 mbsf and \#1800 mbsf do not plot on the linear trends. The air-free helium isotope composition of sample \#950 mbsf is $3.26 \pm 0.28 \mathrm{Ra}$ and thus clearly higher than the air-corrected helium isotopic ratios of all other samples. The latter two samples plot below the mixing lines and thus indicate a higher contribution of crustal helium in addition to mantle helium.

The depth profiles of the ratios ${ }^{3} \mathrm{He} /{ }^{20} \mathrm{Ne},{ }^{4} \mathrm{He} /{ }^{20} \mathrm{Ne}$ and air-corrected ${ }^{3} \mathrm{He} /{ }^{4} \mathrm{He}$ are shown in Fig. 4. Except for sample \#2968.5 (not shown), the ${ }^{3} \mathrm{He} /{ }^{20} \mathrm{Ne}$ and ${ }^{4} \mathrm{He} /{ }^{20} \mathrm{Ne}$ ratios never exceed the atmospheric ratio to more than $20 \%$, i.e. $\geq 80 \%$ of the helium in all samples derives from air. The sample \#2968.5 is more strongly enriched in formation helium, compared with the other samples, because it was taken after pipe tripping ("tripgas") when the well was turned over. When mud pumping is stopped (e.g. during downtime when making a pipe connection or pipe tripping), the downhole pressure is reduced, inducing formation fluids to flow into the borehole (Wiersberg and Erzinger 2011). Apart from its higher helium concentration, the ${ }^{3} \mathrm{He} /{ }^{4} \mathrm{He}$ ratio of sample \#2968.5 is similar to helium isotope ratios from surrounding samples.

Three samples from Exp 338 (\#950, \#1400 and \#1800) show enhanced and rather uniform ${ }^{4} \mathrm{He} /{ }^{20} \mathrm{Ne}$ ratios $(\sim$ $0.37)$, compared to the other samples $(<0.35)$. These three samples derive from depths, which also show elevated radon activity. From these samples, \#950 is also enriched in ${ }^{3} \mathrm{He}\left({ }^{3} \mathrm{He} /{ }^{20} \mathrm{Ne}=7.05 \pm 0.22 \times 10^{-7}\right)$, while all other samples have ${ }^{3} \mathrm{He} /{ }^{20} \mathrm{Ne}$ ratios of $\sim 5 \times 10^{-7}$.

Irrespective of the expedition on which the samples were taken, the air-corrected ${ }^{3} \mathrm{He} /{ }^{4} \mathrm{He}$ ratios are within $2 \sigma$ uncertainty rather uniform at depths below 1850 mbsf. Samples from Exp 338 obtained between 950 and $1850 \mathrm{mbsf}$ are more variable. The air-corrected helium isotope ratio declines from $2.46 \pm 0.49$ at $1700 \mathrm{mbsf}$ down to $0.44 \pm 0.24$ at $1800 \mathrm{mbsf}$ and then increases to $2.59 \pm 0.79$ at 1850 mbsf. While samples $\# 1700$ and \#1850 are, within analytical uncertainties, indistinguishable from the mean ${ }^{3} \mathrm{He} /{ }^{4} \mathrm{He}$ ratio $(\sim 2.40 \mathrm{Ra})$, the ratio for \#1800 is significantly lower.

\section{Discussion}

In this section, we want to relate the results from drilling mud gas analysis to fluid migration processes in the Nankai Trough accretionary prism. Except for samples from 950, 1400 and 1800 mbsf, collected from hole C0002F during Exp 338, all samples from the depth interval from 1700 to 3050 mbsf demonstrate, within a $2 \sigma$ error, similar air-corrected helium isotope compositions with mean ${ }^{3} \mathrm{He} /{ }^{4} \mathrm{He}$ values of $\sim 2.4 \mathrm{Ra}$. As the helium isotope composition from nearby samples can be as low as $0.44 \pm 0.24 \mathrm{Ra}$ (\#1800), we suggest that the relatively constant ${ }^{3} \mathrm{He} /{ }^{4} \mathrm{He}$ ratios for \#1700, \#1850, and all samples from Exp 348 (1.74-2.59 Ra) were not significantly influenced by in situ radiogenic ${ }^{4} \mathrm{He}$ from radioactive decay of $\mathrm{U}$ and/or Th to the observed helium isotope ratios. Higher and more variable $\mathrm{U}$ and $\mathrm{Th}$ concentrations would alter the helium isotope composition towards lower, more crustal values $\left(\left({ }^{3} \mathrm{He} /{ }^{4} \mathrm{He}\right)_{\text {crust }} \sim 0.02 \mathrm{Ra}, \quad\right.$ Mamyrin and Tolstikhin 1984), as it applies for $\# 1400$ and $\# 1800$.

The overall ${ }^{222} \mathrm{Rn}$ activity in the depth interval 1700 3050 mbsf was relatively high during drilling of the C0002P borehole $\left(\sim 300 \mathrm{~Bq} / \mathrm{m}^{3}\right)$ but does not show significant variations with depth, similar to the helium isotopes. The consistently high ${ }^{222} \mathrm{Rn}$ activity at site C0002P could be an artifact from constant inflow of radon-rich fluids from another nearby source into the open hole section during drilling, because the samples from \#1700 and \#1850 mbsf from C0002F have low radon activity $\left(\sim 100 \mathrm{~Bq} / \mathrm{m}^{3}\right)$ but 


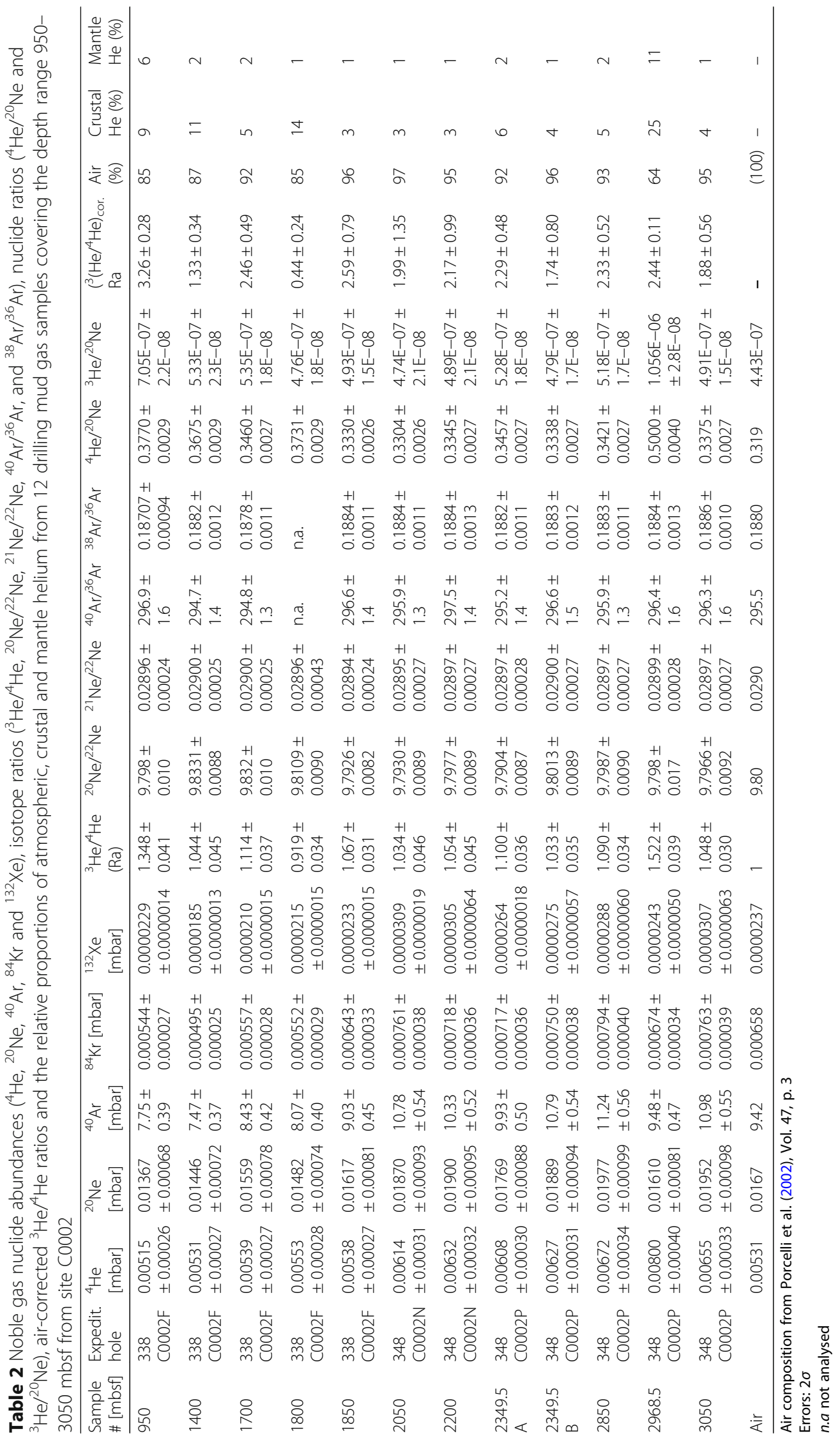



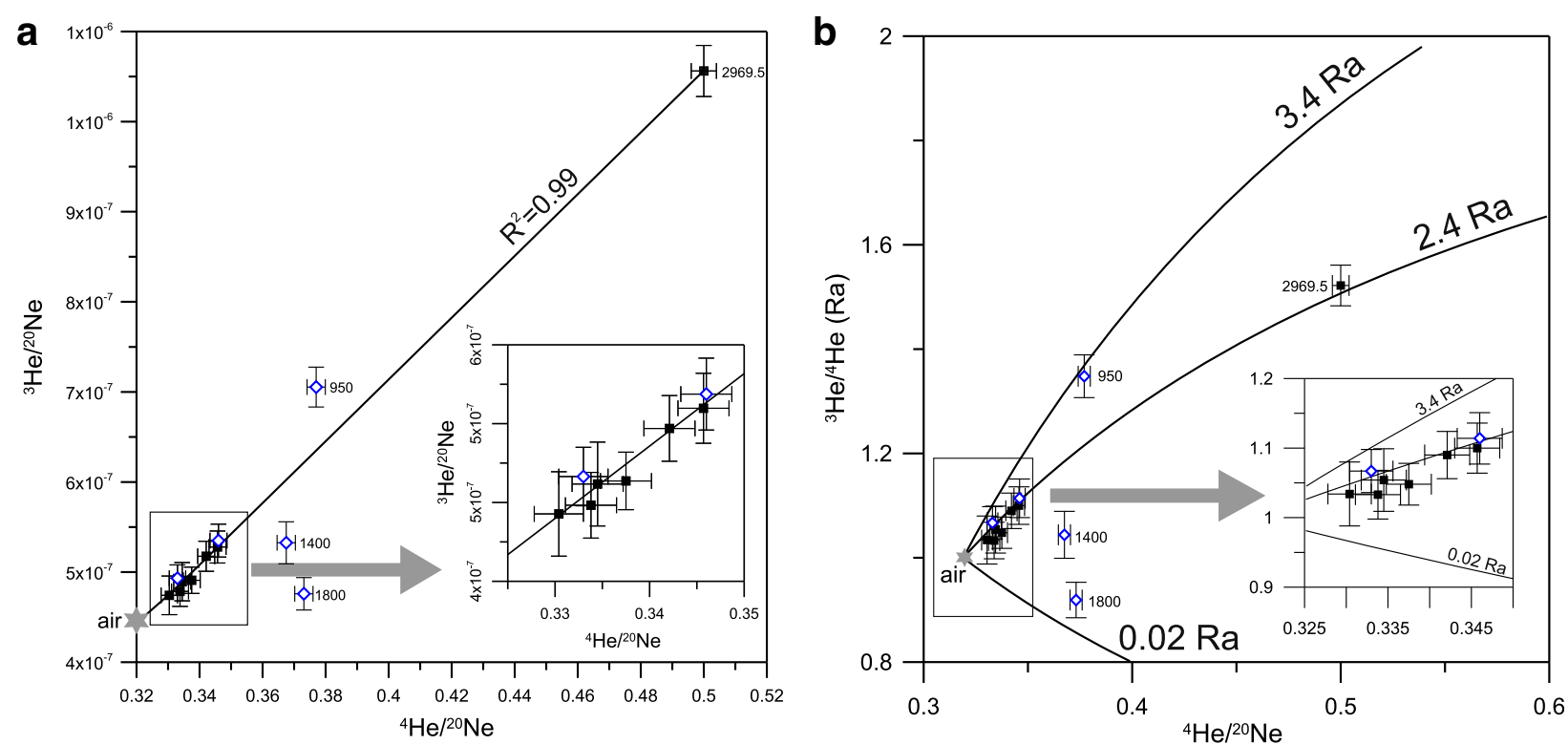

Fig. $3^{3} \mathrm{He} /{ }^{20} \mathrm{Ne}$ vs. ${ }^{4} \mathrm{He} /{ }^{20} \mathrm{Ne}(\mathbf{a})$ and ${ }^{3} \mathrm{He} /{ }^{4} \mathrm{He}$ vs. ${ }^{4} \mathrm{He} /{ }^{20} \mathrm{Ne}$ diagrams (b). In both diagrams, all samples from Exp 348 (black squares) and samples \#1700 and \#1850 from Exp 338 (blue open diamonds) plot on a mixing line between air and a mantle-derived fluid with ${ }^{3} \mathrm{He} /{ }^{4} \mathrm{He}$ composition of $2.40 \pm 0.10 \mathrm{Ra}$ (see text). Hyperbolic lines on diagram $\mathbf{b}$ indicates mixing between air and different reservoir endmembers with ${ }^{4} \mathrm{He} /{ }^{20} \mathrm{Ne}=1000$ and ${ }^{3} \mathrm{He} /{ }^{4} \mathrm{He}=0.02$ (crustal), 2.4 and 3.4, respectively. Numbers denote sample depth

similar, albeit somewhat higher air-corrected ${ }^{3} \mathrm{He} /{ }^{4} \mathrm{He}$ ratios $(2.46 \pm 0.49$ and $2.59 \pm 0.39 \mathrm{Ra})$, compared to samples from Exp 348. Based on rather constant air-corrected helium isotope composition (1.74-2.59 Ra with a mean ratio of $\sim 2.4 \mathrm{Ra}$ ) with no radon anomalies and little helium excess, we assume diffusive migration of fluids containing a mantle helium component through pore space along mineral grain boundaries. Nevertheless, the $\left({ }^{3} \mathrm{He} /{ }^{4} \mathrm{He}\right)_{\text {air-corr. }}$ in this depth interval is lower than for sample \#950 mbsf (3.3 Ra). If we assume that the helium isotope composition of \#950 mbsf is close to the actual values of the subducting PSP in southwest Japan (Umeda et al. 2012) and mantle helium in the interval 3050-1700 mbsf derives from the same source, then admixing of crustal helium must have occurred at depths between $\sim 9 \mathrm{kmbsf}$ (depth of the subducting PSP, Strasser et al. 2014c), and 3050 mbsf (C0002P borehole depth) to yield a mean helium isotope ratio of 2.4 Ra. Admixing with crustal helium is obvious for samples \#1400 and \#1800 with ${ }^{3} \mathrm{He} /{ }^{4} \mathrm{He}$ ratios of $0.44 \pm 0.24$ and $1.33 \pm 0.34$, resp.).

With given age and known concentrations of uranium, thorium, ${ }^{3} \mathrm{He}$ and ${ }^{4} \mathrm{He}$, the ${ }^{3} \mathrm{He} /{ }^{4} \mathrm{He}$ ratio of subducting PSP can be calculated. Umeda et al. (2006a) assume high ${ }^{3} \mathrm{He}\left(5 \times 10^{-11} \mathrm{~cm}^{3} / \mathrm{g} \mathrm{STP}\right)$, uranium $(2.21 \mathrm{ppm})$ and thorium $(5.03 \mathrm{ppm})$ initial concentrations in magma related to Neogene volcanism occurring $14 \mathrm{Ma}$ ago to explain ${ }^{3} \mathrm{He} /{ }^{4} \mathrm{He}$ ratios $\leq 2.5 \mathrm{Ra}$ in hot springs on Shikoku Island. Their calculation yields a ${ }^{3} \mathrm{He} /{ }^{4} \mathrm{He}$ ratio of $\sim 3.4 \mathrm{Ra}$ for the subducting PSP at present. Sano and Nakajima (2008) use concentration values two order of magnitudes lower as basis for their calculation of the ${ }^{3} \mathrm{He} /{ }^{4} \mathrm{He}$ ratio of the subducting PSP $\left({ }^{3} \mathrm{He}=7 \times 10^{-13} \mathrm{~cm}^{3} / \mathrm{g}\right.$ STP, $\left.\mathrm{U}=0.09 \mathrm{ppm}\right)$ and thorium $(0.17 \mathrm{ppm})$, assuming an age of $20 \mathrm{Ma}$ for the slab at the trench and an uncertainty of factor 3 for the ${ }^{3} \mathrm{He}$ concentration. Their calculation, however, yields the same ${ }^{3} \mathrm{He} /{ }^{4} \mathrm{He}$ ratio of $\sim 3.4 \mathrm{Ra}$.

An age of $20 \mathrm{Ma}$ is in agreement with the findings of Okino et al. (1994), verified by coring at Site C0012 (Underwood et al. 2010). However, after $20 \mathrm{Ma}$, significant helium diffusion losses from oceanic crust should have occurred. Also, the high uranium and thorium concentrations reported by Umeda et al. (2006a) and local enrichments of $U$ in the upper part of the accretionary prism reported for interstitial waters sampled at Site C0002 (Expedition 315 Scientists 2009; Strasser et al. 2014b; Expedition 348 Scientists and Scientific Participants 2014) indicate crustal input. We therefore favour the helium input data from Sano and Nakajima and the uranium and thorium concentrations of clay-rich deep-sea sediments (Turekian and Wedepohl 1961) for further calculations. The upward fluid flow rate $q$ can then be estimated according to Kennedy et al. 1997 with

$$
q=\frac{H_{\mathrm{cr}} \rho_{\mathrm{S}} \times P(H e)}{\rho_{\mathrm{f}}\left[{ }^{4} H e\right]_{f, \text { ma }}} *\left[\frac{\left(R /{ }_{\mathrm{Ra}}\right)_{\text {meas }}-\left(R /{ }_{\mathrm{Ra}}\right)_{\mathrm{crust}}}{\left(R /{ }_{\mathrm{Ra}}\right)_{\text {mantle }}-\left(R /{ }_{\mathrm{Ra}}\right)_{\text {meas }}}\right]
$$

where $H_{\mathrm{cr}}$ is the thickness of the crust from the bottom of hole C0002 down to the subducting PSP as 


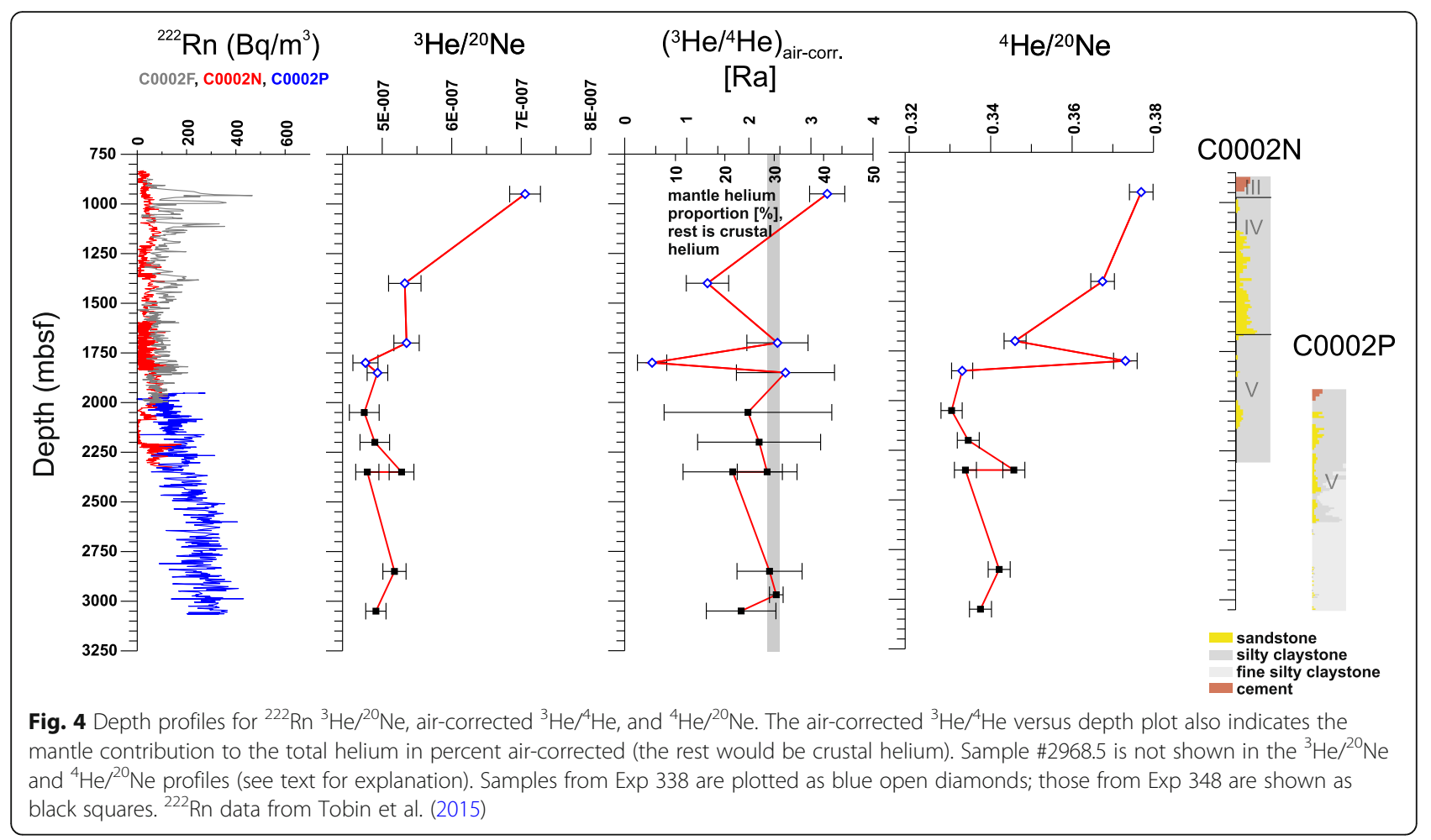

source of the mantle fluids (approx. $6 \mathrm{~km}$, Moore et al. 2015), $\rho_{\mathrm{S}}=2.6 \mathrm{~cm}^{3} / \mathrm{g}$ is the density of the sediments, $\rho_{\mathrm{f}}=1.025 \mathrm{~cm}^{3} / \mathrm{g}$ is the fluid density, $\left[{ }^{4} \mathrm{He}\right]_{f, m a}$ is the concentration of helium in the subducting Philippine Plate $=1.5 \times 10^{-7} \mathrm{~cm}^{3} / \mathrm{g}$ [STP] (Sano and Nakajima 2008). $(R / R a)_{\text {meas }}$, crust, mantle is, relative to the atmospheric ratio, the measured ${ }^{3} \mathrm{He} /{ }^{4} \mathrm{He}$ ratio $(2.4 \mathrm{Ra})$, the average helium production ratio in the crust ( $0.02 \mathrm{Ra}$, Ballentine and Burnard 2002) and the helium isotope ratio of subducting Philippine Sea Plate ( 3.4 Ra, Umeda et al. 2012). $\mathrm{P}(\mathrm{He})$ is the annual radiogenic production and depends on the concentrations of the parent element nuclides ( $\mathrm{U}, \mathrm{Th}$ ). $\mathrm{P}(\mathrm{He})$ can be calculated according to Craig and Lupton (1976) as.

$\mathrm{P}(\mathrm{He})=0.2355 \times 10^{-12} \times \mathrm{U}(1+0.123(\mathrm{Th} / \mathrm{U}-4))$.

Parent element concentrations of $\mathrm{U}=1.2 \mathrm{ppm}$ and $\mathrm{Th}=7 \mathrm{ppm}$ for the accretionary prism (Turekian and Wedepohl 1961) results in an annual radiogenic production $\mathrm{P}(\mathrm{He})$ of $3.46 \times 10^{-13} \mathrm{~cm}^{3} / \mathrm{g}$ [STP] and a resulting flow rate $q$ of $\sim 7 \mathrm{~cm} / \mathrm{a}$. Assuming that instead of vertical flow the fluids would migrate along faults, fractures and bedding planes with a dipping angle of $60^{\circ}$, the calculated flow rate would change to $\sim 10 \mathrm{~cm} / \mathrm{a}$ and to $9 \mathrm{~cm} / \mathrm{a}$ at a $75^{\circ}$ dipping angle, respectively. Given these uncertainties and the not well-constrained helium concentration and helium isotope ratio of the subducting PSP, we suggest a fluid flow on the centimeter scale per year, which is in good agreement with fluid flow calculations in the Nankai Trough based on chlorine measurements (Spivack et al. 2002).

With an estimated fluid flow in the range of 1$10 \mathrm{~cm}$ per year, it would take $\sim 10-100 \mathrm{ka}$ for fluids to travel $6 \mathrm{~km}$ from the subducting PSP at 9-km depth through the accretionary prism to reach the hole bottom depth of C0002P (3050 mbsf). During this time, helium with an isotopic composition $\left({ }^{3} \mathrm{He} /{ }^{4} \mathrm{He}\right)$ of $3.4 \mathrm{Ra}$ would alter to $3.3-2.8 \mathrm{Ra}$. This finding underlines that additional input of crustal helium is required to yield the ${ }^{3} \mathrm{He} /{ }^{4} \mathrm{He}$ ratio found in most samples of our study.

Based on the distribution of gas hydrates in the Nankai Trough, Baba and Yamada (2004) and Yamada et al. (2013) described two mechanisms of fluid migration in accretionary prisms: diffusive fluid flow through intra-granular pore spaces and advective fluid flow through permeable faults. In the deeper part of the prism, fluids expelled by the overburden pressure mainly flow through faults, while diffusive flow is lower in the deeper parts due to lower porosity, and less susceptible to fluctuations. At shallower depths, diffusion is the leading process of fluid migration, leading to a widespread distribution of gas hydrates within the Nankai Trough. According to Yamada et al. (2013), fluid flow in accretionary prisms is also subject to spatial and temporal variations, mainly as a function of faulting and changes in stress field. 
Possible mechanisms that could be involved here are, e.g. hydrofracturing of low-permeable strata, caused by reduction of pore space during deformation at accretionary prisms (Behrmann 1991) and subsequent increase in pore fluid pressure. Numerical models and analog experiments suggested that fluid flow along the thrust faults at the prism toe is generally active, but in periods of inactivity, older, otherwise inactive, thrust faults more landward in the prism are re-activated.

Different fault activity could explain the different radon (high versus low radon activity) and variable helium isotope data from similar depths of holes C0002F, $\mathrm{C} 0002 \mathrm{~N}$ and C0002P. Radon data identified several active faults during Exp 338 (C0002F) at 950, 1100, 1400 and $\sim 1800 \mathrm{mbsf}$, three of which also show unusual ${ }^{3} \mathrm{He} /{ }^{4} \mathrm{He}$ isotope ratios $(1100 \mathrm{mbsf}$ was not sampled). During drilling of C0002N 1 year later, no radon and helium isotope anomalies were detected at these depths (maybe with exception of 1800 mbsf which has not been re-sampled), but radon peaked around 2200 mbsf, where a fault was discovered in C0002P core. Radon data from C0002P do not provide evidence for active fluid flow at that depth, and also the helium isotope ratios were indistinguishable from the mean helium isotope value of Exp 348 (2.4 Ra). We therefore assume diffusion as principle mechanism of helium migration during Exp 338 and Exp 348. In addition, during Exp 338 fluids were encountered at defined depths (950 mbsf, 1400 mbsf, 1800 mbsf and maybe 1100 mbsf) which migrated actively through faults or fractures. A schematic of the fluid migration pathways and processes at site C0002 during Exp 338 (left) and Exp 348 (right) is shown in Fig. 5.

Arc-related volcanism and associated geothermal fluids show generally somewhat lower helium isotope ratios than the canonical $8 \mathrm{Ra}$ for MORB due to possible contamination with crustal fluids during fluid or magma ascent. Hilton et al. 2002 calculated a mean ${ }^{3} \mathrm{He} /{ }^{4} \mathrm{He}$ ratio of $5.4 \pm 1.9 \mathrm{Ra}$ for fluids from arc-related volcanism worldwide. ${ }^{3} \mathrm{He} /{ }^{4} \mathrm{He}$ ratios in agreement with these values were, e.g. observed in samples from hot springs and water wells in the Kinki district (Sano et al. 2009) and in southwest Japan (Chuguko region, Umeda et al. 2012). Supported by seismic tomography and magnetotelluric investigations, which identified a large low-velocity and conductive zone extending from the upper mantle to the middle crust, Umeda et al. (2012) interpreted the high ${ }^{3} \mathrm{He} /{ }^{4} \mathrm{He}$ ratios in southwest Japan close to the volcanic front with upward migration of mantle fluids from an upwelling astenospheric body. For the Kinki district, where high helium isotope ratios were found up to $200 \mathrm{~km}$ away from the volcanic front, Sano et al. (2009) suggest fluid or magma rise from an extinct and subducted mid-ocean ridge.

In contrast, medium $\mathrm{Ra}$ values $(\sim 2-4 \mathrm{Ra})$ in the southwest Japan forearc region were explained by fluid release from the young PSP slab (Sano et al. 2009; Umeda et al. 2012), maybe with additional contribution of crustal fluids. Such medium Ra values are in good agreement with our dataset. Fluid migration from the slab could explain the occurrence of deep non-volcanic tremors in the region. Also the lack of Quaternary volcanism makes a significant contribution of fluids from the asthenosphere to the total fluid budget at site $\mathrm{C0002}$ little likely. We interpret the ${ }^{3} \mathrm{He} /{ }^{4} \mathrm{He}$ ratios measured in $\mathrm{C} 0002$ mud gas samples as a mixture of air, introduced by the downward pumped drilling mud, crustal helium and mantle helium released from the subducting PSP.

$\mathrm{Ra}$ values from arc-related fluids worldwide show a trend towards lower ${ }^{3} \mathrm{He} /{ }^{4} \mathrm{He}$ ratios with increasing slab age due to a combination of mantle helium lost and ingrowth of radiogenic helium (Fig. 6). In comparison with helium isotope data from other active margins worldwide, helium isotope ratios from the Kumano accretionary prism are relatively low, given an age of $20 \mathrm{Ma}$ of the subducting slab. Possible explanations for the comparably low ${ }^{3} \mathrm{He} /{ }^{4} \mathrm{He}$ ratios of our samples, in particular for \#1400 and \#1800, could be (1) higher concentration of parent nuclides ( $U$ and Th), which would result in higher production of radiogenic helium, (2) addition of crustal fluids or (3) mixing with older, more evolved mantle fluids to the fluids released from the subducting PSP. Local enrichments of $U$ in the upper part of the accretionary prism were reported for interstitial waters sampled at Site C0002 (Expedition 315 Scientists 2009; Strasser et al. 2014b; Expedition 348 Scientists and Scientific Participants 2014). Crustal material (wood, lignite) was found in sediments of the Kumano Basin which may call for addition of crustal fluids (Wiersberg et al. 2015). Moreover, several authors (Kimura et al. 2014, Underwood 2018) suggest middle-Miocene migration of a triple junction that would involve subduction of older Pacific Plate sediments near the NanTroSEIZE transect.

\section{Conclusions}

Helium isotope and radon data from 12 drilling mud gas samples obtained between 950 and 3050 mbsf during IODP Expeditions 338 and 348 at the Kumano forearc basin in SW Japan suggest diffusive fluid flow along mineral grain boundaries through the accretionary prism for all samples from Exp 348 and for two of five samples (\#1700, \#1850) from Exp 338. Radon and 


\section{$\operatorname{Exp} 338$}

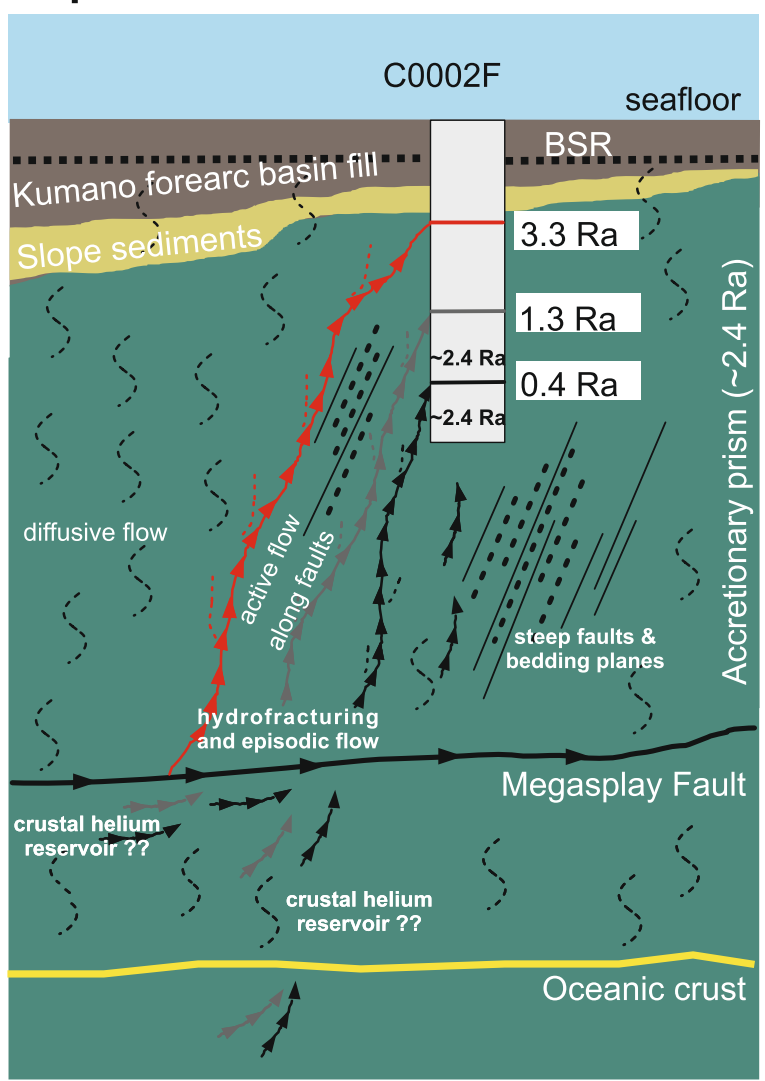

$\operatorname{Exp} 348$

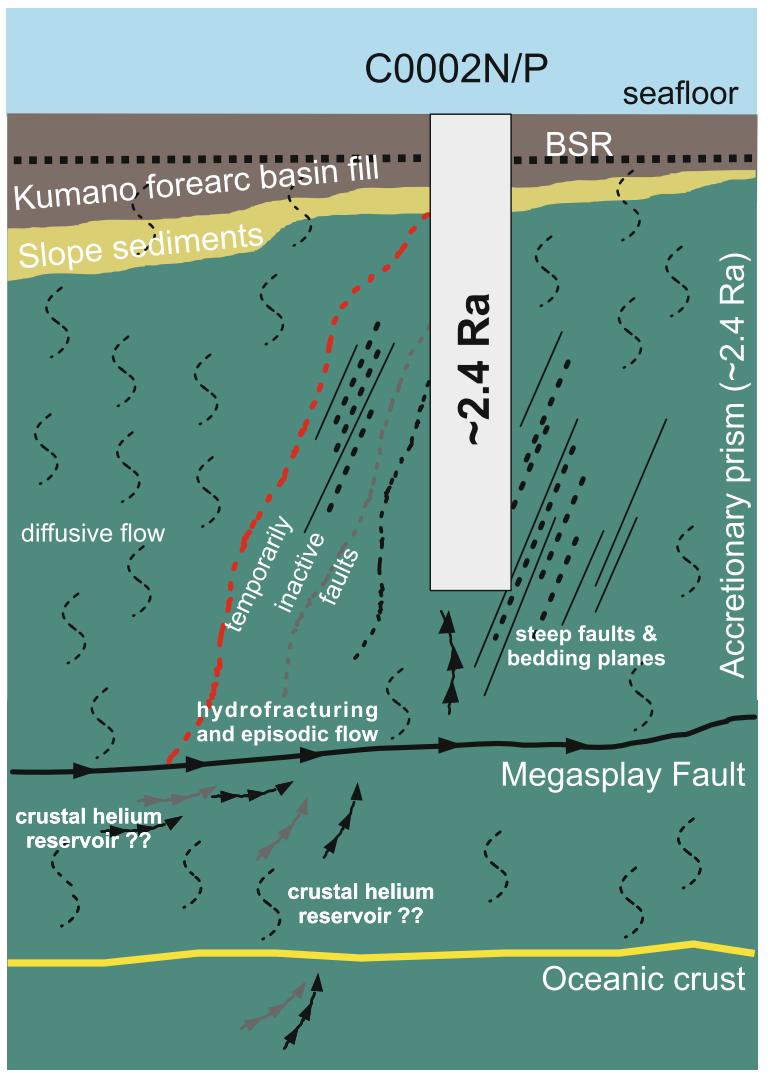

Fig. 5 Conceptual model of fluid flow in the accretionary prism of the Kumano forearc basin during Exp 338 (left diagram) and Exp 348 (right diagram), modified from Yamano et al. 1992 and Moore et al. 2015. While helium isotope and radon data would favour channelized fluid flow at several depths drilled during Exp 338 (red and gray solid lines) in addition to pervasive fluid migration through pore space, the 1 year later Exp 348 bears evidence only for pervasive fluid migration through pore space along mineral grain boundaries with an overall ${ }^{3} \mathrm{He} /{ }^{4} \mathrm{He}$ ratio of $2.4 \mathrm{Ra}$ (dashed curved lines)

helium isotope data of three samples from Exp 338 (\#950, \#1400, \#1800) indicate channelized fluid flow, by which helium from 950 mbsf exhibits a ${ }^{3} \mathrm{He} /{ }^{4} \mathrm{He}$ ratio $(3.3 \mathrm{Ra})$ close to the calculated helium isotope ratio of the subducting Philippine Sea Plate $(\sim 3.4 \mathrm{Ra})$. Two samples (\#1400 and \#1800 mbsf) indicate admixing of crustal helium from a nearby source enriched in uranium and thorium. We suggest that elevated fluid flow caused the observed helium and radon signals of these three samples, according to the fluid flow model from Yamada et al. 2013. Application of the fluid velocity model from Kennedy et al. (1997) results in average fluid velocities in the range of centimeters per year in the accretionary prism of the Kumano Basin.

\section{Acknowledgements}

We want to thank Sean Toczko, Lena Maeda, Yusuke Kubo, Nobu Eguchi, Tomohiro Toki, and the whole crew onboard DN Chikyu for their excellent support during IODP Expeditions 338 and 348. ECORD, IODP Germany and the IODP Priority Program of the German Research Foundation (DFG SPP 527) are greatly acknowledged for funding. The people in charge of noble gas laboratory of the GFZ German Research Centre for Geosciences, namely
Enzio Schnabel and Samuel Niedermann, were of tremendous help in conducting the noble gas analyses. Editor Michael Underwood and two anonymous referees provided helpful and constructive reviews.

\section{Funding}

ECORD, IODP Germany and the IODP Priority Program of the German Research Foundation (DFG SPP 527) are greatly acknowledged for funding.

\section{Availability of data and materials}

Total gas composition data, noble gas abundance and isotope data analysed during this study are included in this published article. Formation age and ${ }^{222} \mathrm{Rn}$ data are published in Strasser et al. 2014C (CO002F) and Tobin et al., 2015 (C0002N/P).

\section{Authors' contributions}

$\mathrm{JE}, \mathrm{AK}, \mathrm{SH}$ and TW proposed the topic and conceived and designed the study. SH and SF carried out the offshore measurements and SH and TW the onshore measurements. TW and SH analysed and interpreted the data. All authors collaborated with the corresponding author in the construction of the manuscript. All authors read and approved the final manuscript.

\section{Competing interests}

The authors declare that they have no competing interest. 


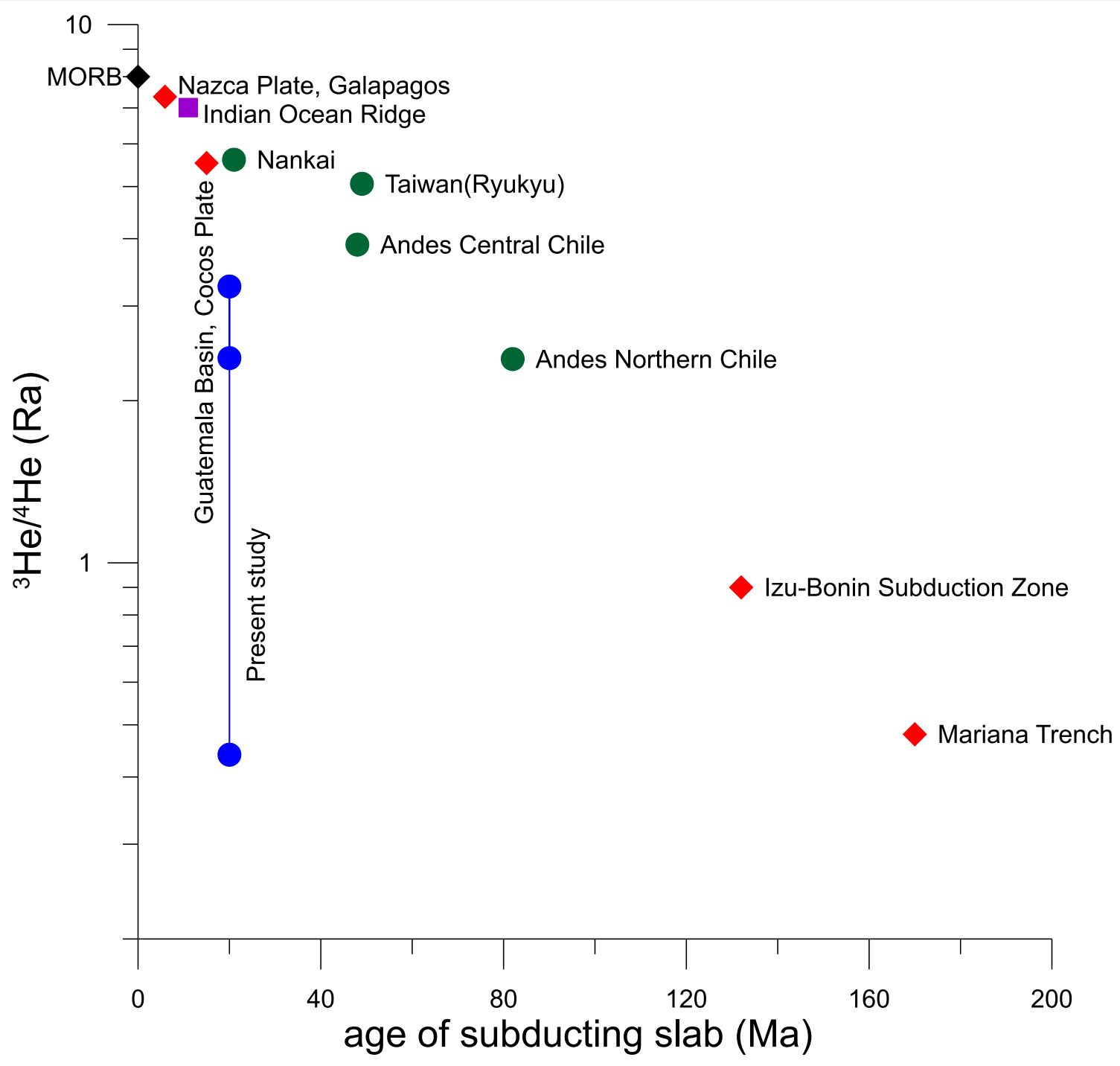

Fig. 6 Mean Ra values from arc-related fluids worldwide versus age of the subducted sediment. Data from Hilton et al. 2002 (green circles), Moreira et al. 2003 (purple square) and Chavrit et al. 2016 (red diamonds). The trend to lower helium isotope ratios with increasing slab age is due to a combination of mantle helium lost and ingrowth of radiogenic helium. Own data (blue circles) show additional input of crustal helium from another source

\section{Publisher's Note}

Springer Nature remains neutral with regard to jurisdictional claims in published maps and institutional affiliations.

\section{Author details}

${ }^{1}$ Helmholtz Centre Potsdam, GFZ German Research Centre for Geosciences, Telegrafenberg, D-14473 Potsdam, Germany. ${ }^{2}$ MARUM - Center for Marine Environmental Sciences, University of Bremen, PO Box 330440, D-28334 Bremen, Germany. ${ }^{3}$ National Institute for Environmental Studies-Japan, 16-2 Onogawa, Tsukuba, Ibaraki Prefecture 305-0053, Japan.

Received: 1 March 2018 Accepted: 23 October 2018

Published online: 29 November 2018

\section{References}

Aquilina L, Baubron J-C, Defoix D, Dégranges P, Disnar J-R, Marty B, Robé M-C (1998) Characterization of gases in sedimentary formations through monitoring during drilling and core leaching (Balazuc borehole, deep geology of France Programme). Appl Geochem 13:673-686. https://doi.org/ 10.1016/s0883-2927(98)00008-0

Ashi J, Lallement S, Masago H, the Expedition 315 Scientists (2009) Expedition 315 Summary. In: Kinoshita M, Tobin H, Ashi J, Kimura G, Lallement S, Screaton EJ, Curewitz D, Masago H, Moe KT, Expedition 314/315/316 Scientists (eds) Proc IODP 314/315/316. Integrated Ocean Drilling Program Management International, Inc, Tokyo. https://doi.org/10.2204/iodp.proc. 314315316.121.2009

Baba K, Yamada Y (2004) BSRs and associated reflections as an indicator of gas hydrate and free gas accumulation - an example of accretionary prism and forearc basin system along the Nankai Trough, off Central Japan. Resour Geol 54:11-24

Ballentine CJ, Burnard PG (2002) Production, release and transport of Noble gases in the continental crust. Rev Mineral Geochemistry 47:481-538. https://doi. org/10.2138/rmg.2002.47.12

Behrmann J (1991) Conditions for hydrofracture and the fluid permeability of accretionary wedges. Earth Planet Sci Lett 107:550-558

Burnard P, Bourlange S, Henry P, Geli L, Tryon MD, Natal'in B, MC SA, Özeren MS, Çagatay MN (2012) Constraints on fluid origins and migration velocities 
along the Marmara Main Fault (Sea of Marmara, Turkey) using helium isotopes. Earth Planet Sci Lett 341-344:68-78. https://doi.org/10.1016/j.epsl. 2012.05.042

Chaduteau C, Jean-Baptiste P, Fourre E, Charlou JL, Donval JP (2009) Helium transport in sediment pore fluids of the Congo-Angola margin. Geochm Geophys Geosyst 10:1-12. https://doi.org/10.1029/2007GC001897

Chavrit D, Burgess R, Sumino H, Teagle DAH, Droop G, Shimizu A, Ballentine CJ (2016) The contribution of hydrothermally altered ocean crust to the mantle halogen and noble gas cycles. Geochim Cosmochim Acta 183:106-124

Clark WB, Beg MA, Craig H (1969) Excess 3 He in the sea: Evidence for terrestrial primordial helium. Earth Planet Sci Lett 6:213-220

Craig H, Lupton JE (1976) Primordial neon, helium, and hydrogen in oceanic basalts. Earth Planet Sci Lett 31:369-385. https://doi.org/10.1016/0012821X(76)90118-7

Craig H, Lupton JE, Horibe Y (1978) A mantle helium component in circum Pacific volcanic glasses: Hakone, the Marianas, and Mt Lassen. In: Alexander EC, Ozima M (eds) Terrestrial Rare Gases. Jpn. Sci. Soc.Press, Tokyo, pp 3-16

Doan M-L, Conin M, Henry P, Wiersberg T, Boutt D, Buchs D, Saffer D, McNeill L, Cukur CD, Lin W (2011) Quantification of free gas in the Kumano fore-arc basin detected from borehole physical properties: IODP Nan TroSEIZE drilling Site C0009A. Geochm Geophys Geosyst, 12, Q0AD06, doi: https://doi.org/10. 1029/2010GC003284

Doğan T, Sumino H, Nagao K, Notsu K (2006) Release of mantle helium from forearc region of the Southwest Japan arc. Chem Geol 233(3):235-248

Dunai TJ, Baur H (1995) Helium, Neon, and Argon Systematics of the European Subcontinental Mantle - Implications for Its Geochemical Evolution. Geochimica Et Cosmochimica Acta 59(13):2767-2783

Erzinger J, Wiersberg T, Zimmer M (2006) Real-time mud gas logging and sampling during drilling. Geofluids 6:225-233

Expedition 315 Scientists (2009) Expedition 315 Site C0002. In: Kinoshita M, Tobin H, Ashi J, Kimura G, Lallemant S, Screaton EJ, Curewitz D, Masago H, Moe KT, the Expedition 314/315/316 Scientists (eds) Proc IODP 315. Integrated Ocean Drilling Program Management International, Inc, Washington D.C

Expedition 348 Scientists and Scientific Participants (2014) Expedition 348 Preliminary Report NanTroSEIZE Stage 3 : NanTroSEIZE plate boundary deep riser 3. IODP Prelim Rep 348:71. https://doi.org/10.2204/iodp.pr.348.2014

Graham DW (2002) Noble gas isotope geochemistry of mid-ocean ridge and ocean island basalts: characterization of mantle source reservoirs. Rev Mineral Geoche 47:247-317. https://doi.org/10.2138/rmg.2002.47.8

Hammerschmidt S (2014) Monitoring of deep fluids in the Nankai subduction complex, SE offshore Japan. Dissertation, University Bremen

Hammerschmidt S, Wiersberg T, Heuer VB, Wendt J, Erzinger J, Kopf A (2014) Realtime drilling mud gas monitoring for qualitative evaluation of hydrocarbon gas composition during deep sea drilling in the Nankai Trough Kumano Basin. Geochem Trans 15(15). https://doi.org/10.1186/s12932-014-0015-8

Hayman NW, Byrne T, McNeill LC, Kanagawa KT, Brown CM, Schleicher AM, Huftile GJ (2012) Structural evolution of an inner accretionary wedge and forearc basin initiation, Nankai margin, Japan. Earth Planet Sci Lett 353-354: $163-172$

Hilton DR, Craig H (1989) A helium isotope transect along the Indonesian archipelago. Nature 342:906

Hilton DR, Fischer TP, Marty B (2002) Noble gases and volatile recycling at subduction zones. Rev Mineral Geochem 47:319-370. https://doi.org/10.2138/ rmg.2002.47.9

Hüpers A, Kasemann SA, Kopf AJ, Meixner A, Toki T, Shinjo R, Wheat CG, You C-F (2016) Fluid flow and water-rock interaction across the active Nankai Trough subduction zone forearc revealed by boron isotope geochemistry. Geochim Cosmochim Acta 193:100-118

Kennedy BM, Kharaka YK, Evans WC, Ellwood A, DePaolo DJ, Thordsen J, Ambats G, Mariner RH (1997) Mantle Fluids in the San Andreas Fault System, California. Science 278:1278-1281. https://doi.org/10.1126/science.278. 5341.1278

Kennedy BM, van Soest MC (2007) Flow of mantle fluids through the ductile lower crust: helium isotope trends. Science 318:1433-1436. https://doi.org/10. 1126/science.1147537

Kimura G, Hashimoto Y, Kitamura Y, Yamaguchi A, Koge H (2014) Middle Miocene swift migration of the TाT triple junction and rapid crustal growth in Southwest Japan—a review. Tectonics. https://doi.org/10.1002/ 2014 TC003531

Kinoshita M, Shiraishi K, Demetriou E, Hashimoto Y, Lin W (2018) Geometrical dependence of the stress and slip tendency acting on the subduction megathrust of Nankai seismogenic zone off Kumano. In: EGU general assembly 2018, Geophysical Research Abstracts, vol 20, EGU2018-18742

Kipfer R, Aeschbach-Hertig W, Peeters F, Stute M (2002) Noble gases in lakes and ground waters. Rev Mineral Geochem 47:615-700. https://doi.org/10.2138/ rmg.2002.47.14

Kopf A, Araki E, Toczko S, the Expedition 332 Scientists (2011) Proc IODP, 332. Integrated Ocean Drilling Program Management International, Inc, Tokyo

Kopf A, Deyhle A, Lavrushin VY, Polyak BG, Gieskes JM, Buachidze Gl, Wallmann K, Eisenhauer A (2003) Isotopic evidence (He, B, C) for deep fluid and mud mobilization from mud volcanoes in the Caucasus continental collision zone. Int J Earth Sci 92:407-425. https://doi.org/10.1007/s00531-003-0326-y

Kopf AJ (2002) Significance of mud volcanism. Rev Geophys 40:1005. https://doi. org/10.1029/2000rg000093

Mamyrin BA, Tolstikhin IN (1984) Helium isotopes in nature. Elsevier, New York

Matsumoto T, Kawabata T, Matsuda J, Yamamoto K, Mimura K (2003) 3He/4He ratios in well gases in the Kinki district, SW Japan: surface appearance of slab-derived fluids in a non-volcanic area in Kii peninsula. Earth Planet Sci Lett 216:221-230. https://doi.org/10.1016/S0012-821X(03)00479-5

Miyazaki S, Heki K (2001) Crustal velocity field of Southwest Japan: subduction and arc-arc collision. J Geophys Res 106:4305-4326. https://doi.org/10.1029/ 2000jb900312

Moore GF, Boston BB, Strasser M, Underwood MB, Ratliff RA (2015) Evolution of tectono-sedimentary systems in the Kumano Basin, Nankai Trough forearc. Mar Pet Geol 67:604-616. https://doi.org/10.1016/j.marpetgeo.2015.05.032

Moore GF, Kanagawa K, Strasser M, Dugan B, Maeda L, Toczko S, The Expedition 338 Scientists (2013) NanTroSEIZE stage 3: NanTroSEIZE plate boundary deep riser. IODP Prelim Rep 338. https://doi.org/10.2204/iodp.pr.338.2013

Moore GF et al (2009) Structural and seismic stratigraphic framework of the NanTroSElZE stage 1 transect. Proc IODP 314/315/316. https://doi.org/10. 2204/iodp.proc.314315316.102.2009

Moreira M, Blusztajn J, Curtice J, Hart S, Dick H, Kurz M (2003) He and Ne isotopes in oceanic crust: implications for noble gas recycling in the mantle. Earth Planet Sci Lett 216(4):635-643. https://doi.org/10.1016/S0012-821X(03)00554-5

Niedermann S, Bach W, Erzinger J (1997) Noble gas evidence for a lower mantle component in MORBs from the southern East Pacific rise: decoupling of helium and neon isotope systematics. Geochim Cosmochim Acta 61:26972715. https://doi.org/10.1016/S0016-7037(97)00102-6

Nishio Y, ljiri A, Toki T, Morono Y, Tanimizu M, Nagaishi K, Inagaki F (2015) Origins of lithium in submarine mud volcano fluid in the Nankai accretionary wedge. Earth Planet Sci Lett Vol 414:144-155. https://doi. org/10.1016/j.epsl.2015.01.018

Okino K, Shimakawa Y, Nagaoka S (1994) Evolution of the Shikoku Basin. J Geomagn Geoelectr 46(6):463-479

Pape T, Geprägs P, Hammerschmidt S, Wintersteller P, Wei J, Fleischmann T, Bohrmann G, Kopf AJ (2014) Hydrocarbon seepage and its sources at mud volcanoes of the Kumano forearc basin, Nankai Trough subduction zone. Geochem, Geophys Geosyst 15:2180-2194. https://doi.org/10.1002/ 2013GC005057

Poreda R, Craig H (1989) Helium isotope ratios in circum-Pacific volcanic arcs. Nature 338:473

Poricelli D, Ballentine CJ, Wieler R (2002) An Overview on Noble Gas Geochemistry and Cosmochemistry. Rev. Mineral Geochemistry 47:1-19. https://doi.org/10.2138/rmg.2002.47.1.

Sano Y, Kameda A, Takahata N, Yamamoto J, Nakajima J (2009) Tracing extinct spreading center in SW Japan by helium-3 emanation. Chem Geol 266:5056. https://doi.org/10.1016/j.chemgeo.2008.10.020

Sano Y, Nakajima J (2008) Geographical distribution of $3 \mathrm{He} / 4 \mathrm{He}$ ratios and seismic tomography in Japan. Geochem J 42:51-60

Screaton E, Kimura G, Curewitz D, Moore G, Chester F, Fabbri O, Fergusson C, Girault F, Goldsby D, Harris R, Inagaki F, Jiang T, Kitamura Y, Knuth M, Li C, Claesson Liljedahl L, Louis L, Milliken K, Nicholson U, Riedinger N, Sakaguchi A, Solomon E, Strasser M, Su X, Tsutsumi A, Yamaguchi A, Ujiee K, Zhao X (2009) Interactions between deformation and fluids in the frontal thrust region of the NanTroSEIZE transect offshore the Kii Peninsula, Japan: Results from IODP Expedition 316 Sites C0006 and C0007. Geochem Geophys Geosys 10(Q0AD01):1-14

Seno T, Stein S, Gripp AE (1993) A model for the motion of the Philippine Sea plate consistent with NUVEL-1 and geological data. J Geophys Res 98:17941-17948

Spivack AJ, Kastner M, Ransom B (2002) Elemental and isotopic chloride geochemistry and fluid flow in the Nankai Trough. Geophys Res Lett 29(14):6-1-6-4 
Strasser M, Dugan B, Kanagawa K, Moore GF, Toczko S, Maeda L, Kido Y, Moe KT, Sanada Y, Esteban L, Fabbri O, Geersen J, Hammerschmidt S, Hayashi H, Heirman K, Hüpers A, Jurado MJ, Kameo K, Kanamatsu T, Kitajima H, Masuda H, Milliken K, Mishra R, Motoyama I, Olcott K, Oohashi K, Pickering KT, Ramirez SG, Rashid H, Sawyer D, Schleicher A, Shan Y, Skarbek R, Song I, Takeshita T, Toki T, Tudge J, Webb S, Wilson DJ, Wu H, Yamaguchi A (2014c) Site C0002. In: Strasser et al (eds) IODP Proc 338:248. https://doi.org/10.2204/ iodp.proc.338.103.2014

Strasser M, Dugan B, Kanagawa K, Moore GF, Toczko S, Maeda L, Kido Y, Moe KT, Sanada Y, Esteban L, Fabbri O, Geersen J, Hammerschmidt S, Hayashi H, Heirman K, Hüpers A, Jurado Rodriguez MJ, Kameo K, Kanamatsu T, Kitajima H, Masuda H, Milliken K, Mishra R, Motoyama I, Olcott K, Oohashi K, Pickering KT, Ramirez SG, Rashid H, Sawyer D, Schleicher A, Shan Y, Skarbek R, Song I, Takeshita T, Toki T, Tudge J, Webb S, Wilson DJ, Wu H-Y, Yamaguchi A (2014b) Methods. In: Strasser et al (eds) IODP Proc 338:92. https://doi.org/10. 2204/iodp.proc.338.102.2014

Strasser M, Dugan B, Kanagawa K, Moore GF, Toczko S, Maeda L, the Expedition 338 Scientists (2014a) Proc. IODP, 338. Integrated Ocean Drilling Program, Yokohama. https://doi.org/10.2204/iodp.proc.338.2014

Strasser M, Moore GF, Kimura G, Kitamura Y, Kopf A, Lallemant S, Park J-O, Screaton EJ, Su X, Underwood MB, Zhao X (2009) Origin and evolution of a splay fault in the Nankai accretionary wedge. Nat Geosci 2:648

Sugihara T, Kinoshita M, Araki E, Kimura T, Kyo M, Namba Y, Kido Y, Sanada Y, Thu MK (2014) Re-evaluation of temperature at the updip limit of locked portion of Nankai megasplay inferred from IODP site C0002 temperature observatory. Earth Planets Space 66:107

Taira A (2001) Tectonic evolution of the Japanese island arc system. Annu Rev Earth Planet Sci 29:109-134

Tobin H, Hirose T, Saffer D, Toczko S, Maeda L, Kubo Y, the Expedition 348 Scientists (2015) Proc. IODP, 348. Integrated Ocean Drilling Program, College Station. https://doi.org/10.2204/iodp.proc.348.2015

Tobin H, Saffer D (2009) Elevated fluid pressure and extreme mechanical weakness of a plate boundary thrust, Nankai Trough subduction zone. Geology 37(8):679-682

Tomaru H, Fehn U (2014) Movement of fluids in the Nankai Trough area: insights from 129 and halogen distributions along the IODP NanTroSEIZE transect. Geochem Cosmochem Acta 149:64-78

Turekian KK, Wedepohl KH (1961) Distribution of the elements in some major units of the Earth's crust. Geol Soc Am Bull 72:175-192. https://doi.org/10. 1130/0016-7606(1961)72

Umeda K, Kanazawa S, Kakuta C, Asamori K, Oikawa T (2006a) Variations in the $3 \mathrm{He} / 4 \mathrm{He}$ ratios of hot springs on Shikoku Island, Southwest Japan. Geochem Geophys Geosyst 7:Q04009. https://doi.org/10.1029/2005GC001210

Umeda K, Kusano T, Asamori K, McCrank GF (2012) Relationship between 3He/4He ratios and subduction of the Philippine Sea plate beneath Southwest Japan. J Geophys Res Solid Earth 117:B10204. https://doi.org/10.1029/2012JB009409

Umeda K, McCrank GF, Ninomiya A (2007a) Helium isotopes as geochemical indicators of a serpentinized fore-arc mantle wedge. J Geophys Res Solid Earth 112:B10206. https://doi.org/10.1029/2007JB005031

Umeda K, Ogawa Y, Asamori K, Oikawa T (2006b) Aqueous fluids derived from a subducting slab: observed high $3 \mathrm{He}$ emanation and conductive anomaly in a non-volcanic region, Kii Peninsula Southwest Japan. J Volcanol Geotherm Res 149:47-61. https://doi.org/10.1016/j.jvolgeores.2005.06.005

Umeda K, Sakagawa Y, Ninomiya A, Asamori K (2007b) Relationship between helium isotopes and heat flux from hot springs in a non-volcanic region, Kii Peninsula, Southwest Japan. Geophys Res Lett 34:L05310. https://doi.org/10. 1029/2006GL028975

Underwood MB (2018) The origin of strata within the inner accretionary prism of Nankai Trough: evidence from clay mineral assemblages along the NanTroSEIZE transect. Island Arc 27(3) https://doi.org/10.1111/iar.12252.

Underwood MB, Saito S, Kubo Y, the Expedition 322 Scientists (2010) Expedition 322 summary. In: Saito S, Underwood MB, Kubo Y, the Expedition 322 Scientists (eds) Proc. IODP, 322. Integrated Ocean Drilling Program Management International, Inc, Tokyo. https://doi.org/10.2204/iodp.proc.322.101.2010

Wakita H, Sano Y, Mizoue M (1987) High 3He emanation and seismic swarms observed in a nonvolcanic, forearc region. J Geophys Res Solid Earth 92: 12539-12546. https://doi.org/10.1029/JB092iB12p12539

Wang K, Hu Y (2006) Accretionary prisms in subduction earthquake cycles: the theory of dynamic coulomb wedge. J Geophys Res 111:B06410. https://doi. org/10.1029/2005JB004094
Whiticar MJ (1994) Correlation of natural gases with their sources. In: Magoon LB, Dow WG (eds) The Petroleum System-From Source to Trap, AAPG Memoir 60:261-283

Wiersberg T, Erzinger J (2007) A helium isotope cross-section study through the San Andreas Fault at seismogenic depths. Geochem Geophys Geosyst 8: Q01002. https://doi.org/10.1029/2006gc001388.

Wiersberg et al. (2011): Wiersberg, T., Süer, S., Güleç, N., Erzinger, J., and Parlaktuna, M. (2011) Noble gas isotopes and the chemical composition of geothermal gases from the Büyük Menderes Graben (Western Anatolia, Turkey). Journal of Volcanology and Geothermal Research 208:112-121. https://doi.org/10.1016/j.jvolgeores.2011.09.009.

Wiersberg T, Erzinger J (2011) Chemical and isotope compositions of drilling mud gas from the San Andreas Fault Observatory at Depth (SAFOD) boreholes: Implications on gas migration and the permeability structure of the San Andreas Fault. Chem Geol 284:148-159. https://doi.org/10.1016/j. chemgeo.2011.02.016

Wiersberg T, Schleicher AM, Horiguchi K, Doan M-L, Equchi N, Erzinger J (2015) Origin and in situ concentrations of hydrocarbons in the Kumano forearc basin from drilling mud gas monitoring during IODP NanTroSEIZE Exp. 319. Appl Geochem 61:206-216 ISSN 0883-2927, https://doi.org/10.1016/j. apgeochem.2015.06.002

Yamada Y, Baba K, Miyakawa A, Matsuoka T (2013) Granular experiments of thrust wedges: insights relevant to methane hydrate exploration at the Nankai accretionary prism. Mar Pet Geol 51:34-48. https://doi.org/10.1016/j. marpetgeo.2013.11.008

Yamano M, Foucher J-P, Kinoshita M, Fisher A, Hyndman RD, ODP leg 131 shipboard scientific party (1992) Heat flow and fluid flow regime in the western Nankai accretionary prism. Earth Plan Sci Lett 109:451-462

\section{Submit your manuscript to a SpringerOpen ${ }^{\circ}$ journal and benefit from:}

- Convenient online submission

- Rigorous peer review

- Open access: articles freely available online

High visibility within the field

- Retaining the copyright to your article

Submit your next manuscript at $\boldsymbol{\nabla}$ springeropen.com 